\title{
Lőrincz Andrea: „Itt ezek a kis házikók az intézetet szimbolizálják” Történetek egy gyermekotthon lakóiról - a tetoválások tükrében ${ }^{1}$
}

\begin{abstract}
Absztrakt
2015-től folytatott önkéntes tevékenységem során számos állami gondoskodás alatt álló fiatallal találkoztam, akiknek köszönhetően kultúrájuk több elemét is megismerhettem. Jelenlegi és jövőbeli kutatómunkáim során ennek a kultúrának a sajátosságait szeretném részletesen feltárni és leírni. Tanulmányomban a bőrre festett képi kifejezésmódoknak, vagyis a tetoválásoknak szentelek kiemelt figyelmet. Ehhez a téma szakirodalmának feldolgozása és a több hónapon átívelő, rendszeres, dokumentált megfigyelések mellett 19 fiatalt és 6 egyéb kulcsadatközlőt kérdezek meg - elsősorban - strukturált interjúban.

Mára a tetoválások széles körben elterjedtek, így azokat már nem tekinthetjük valamilyen deviáns magatartásforma megnyilvánulásának. Manapság a testmódosítás e formáját az önkifejezés egyik eszközeként tartja számon a szakirodalom. A gyermekotthonban látott tetoválások kapcsán felmerült bennem a kérdés: vajon ezek a testmódosítások az önkifejezést szolgálják? Vagy a frusztráció csökkentését, esetleg az időstrukturálást célozzák meg? A kutatásom során elsődleges célom, hogy a fiatalok tetováltatáshoz vezető motivációján és a tetoválások motívumkészletén keresztül bemutassam, hogy a bőrfelületeken megjelenő ábrák képesek térképként szolgálni a gyermekotthon világának megismeréséhez.
\end{abstract}

Kulcsszavak: gyermekvédelem, testmódosítás, tetoválás, kvalitatív kutatás, szociálpedagógia

\begin{abstract}
In our days tattoos have spread widely, so we cannot consider them as manifestations of deviant behaviour. Nowadays this form of body modification is known to be a tool of selfexpression by the literature. But from the tattoos seen in orphanages, the question arises in me whether these body modifications are on the first place to express themselves. Besides answering this question my main aim is to discover the motivation of having a tattoo and its motifs and introduce how these pictures on the skin can be a map to gain knowledge about the world of orphanages.

My qualitative research based on interviews and participant observation has taken place in an orphanage. I would like to reveal and note the detailed features of this culture. In my essay I would like to pay particular attention to tattoos. For this I asked questions from 19 youngsters and 6 other informants with the help of structured interviews.
\end{abstract}

Keywords: protection of children, body modification, tattoo, qualitative research, social pedagogy

\footnotetext{
${ }^{1}$ A tanulmány egyes részei korábban közlésre kerültek: Lőrincz 2017a.
} 


\section{Bevezetés}

„, Gyakorlatilag ide várt gyerek nem érkezik. Úgy még én nem kaptam gyereket, hogy

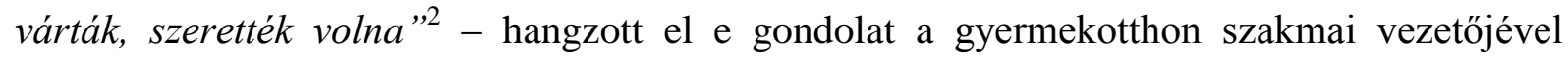
készített interjúm során. Kezdetben meghökkentő és szinte elképzelhetetlen igazságtartalommal bírt ez az állitás, azonban kutatásom elörehaladtával egyre reálisabbá vált, hogy tévúton jár a közvélekedés, miszerint a családok legnagyobb szétszakító ereje anyagi eredetü. Ma igenis szerves részét képezi a társadalom életének a gyermekek bántalmazása és a családok ezen okból való szétválasztása.

Magyarországon jelenleg több gyermekotthon müködik, melyek otthont nyújtó ellátást biztosítanak azon gyermekek számára, akik különböző okokra visszavezethetően, nem élhetnek vér szerinti családjuk körében. Résztvevő megfigyelésre és interjúkra épülő kvalitatív kutatásomat ezen intézmények egyikében végeztem.

2015-től folytatott önkéntes tevékenységem során számos gyermekvédelmi gondoskodásban lévő fiatallal találkoztam, akiknek köszönhetően kultúrájuk több elemét is megismerhettem. Hamar realizálódott bennem, hogy egy Janus-arcú intézmény kapuja tárult ki elöttem, ahová egy olyan szerepben léphettem be, amelyből mindkét fél jól láthatóvá vált. Az otthon hivatalos célja a társadalomba való integráció elősegítése, a gyermekek kiemelése a társadalom perifériájáról. Jelen kutatásom azonban nem ezen célok megvalósulására (vagy meg nem valósulására) fókuszál, hanem az itt élő gyerekek, fiatalok kulturális jellegzetességeit veszi górcső alá. Jelenlegi és jövőbeli kutatómunkáim során ennek a kultúrának a sajátosságait szeretném részletesen feltárni és leírni. Tanulmányomban a bőrre festett képi kifejezésmódoknak, vagyis a tetoválásoknak szentelek kiemelt figyelmet. Ehhez a téma szakirodalmának feldolgozása és a több hónapon átívelő, rendszeres, dokumentált megfigyelések mellett 19 fiatalt és 6 további kulcsadatközlőt (szakmai vezetőt, nevelőket, tetoválókat) kérdeztem meg strukturált, illetve félig strukturált interjúban.

Mára a tetoválások széles körben elterjedtek, így azokat már nem tekinthetjük valamilyen deviáns magatartásforma megnyilvánulásának. Manapság a testmódosítás e formáját az önkifejezés egyik eszközeként tartja számon a szakirodalom. A gyermekotthonban látott tetoválások kapcsán azonban felmerült bennem a kérdés: vajon ezek a testmódosítások is elsősorban önkifejezésre szolgálnak, mi céljuk lehet az önkifejezésen túl? Vajon a frusztráció csökkentését, esetleg az időstrukturálást célozzák? Számtalan további kérdés is megfogalmazódott bennem e zárt közösség tetováltatási szokásait illetően. E kérdések megválaszolása mellett azonban elsősorban mégis az a célom, hogy a fiatalok tetováltatáshoz vezető motivációján és a tetoválások motívumkészletén keresztül bemutassam, hogy a bőrfelületeken megjelenő ábrák és feliratok képesek térképként szolgálni a gyermekotthon világának megismeréséhez.

\section{A kutatás bemutatása}

Jelen tanulmány célja egy gyermekotthon szubkulturális sajátosságainak feltárására fókuszáló kutatásom bemutatása, mely elsősorban a testmódosító eljárásokat veszi górcső alá.

\footnotetext{
${ }^{2}$ Részlet az intézmény szakmai vezetőjével készített interjúból.
} 
Bevezetésként azt a néhány gondolatot kívánom megfogalmazni, melyek véleményem szerint, engem mint kutatót és magát a kutatómunkámat leginkább jellemzik.

1. Kutatásom alapvető módszerének a résztvevő megfigyelés tekinthető, mely során törekedtem a gyermekotthon közösségébe való beilleszkedésre, ezáltal az eseményeket és benyomásokat a közösség tagjaként, valamint külső szemlélőként egyaránt értelmezhettem. A módszer melletti elkötelezettségem elsősorban önkéntes tapasztalataimra, valamint személyes érdeklődésemre vezethető vissza.

2. Bár a tapasztalatok azt mutatják, hogy a legtöbb adatot a nem strukturált interjúk termelik (Corbin, Strauss 2008), én mégis inkább a strukturált interjú típusát alkalmaztam, annak érdekében, hogy könnyebbé váljon kutatásom fókuszának megtartása a számomra és fiatal adatközlőim számára is igen impulzív és szenzitív interjúszituációkban.

3. Kutatásom minden tekintetben a kvalitatív kutatás szemléleti keretei között zajlott. Fontos volt számomra, hogy a kutatási területemen keresztül minél közelebb kerüljek az adatközlőkhöz, ezáltal egy lépésről lépésre kibontakozó, dinamikus folyamat részesei legyünk mindannyian. Erre a kapcsolatra alapozva a merev, statisztikai alapokon nyugvó, elemző kutatói tevékenység helyett egy személyes kapcsolatokból s egyedi esetekből építkező, feltáró munkát folytathattam, melyből a működési mechanizmusok s az ok-okozati összefüggések általánosan is leírhatók.

4. A kutatás és az írás folyamatában is törekedtem a „reflexív szubjektivitás” (Mészáros 2014: 119), „fegyelmezett szubjektivitás” (Golnhofer 2001: 50) alkalmazására, ennek hatására vártam, hogy megvalósuljon olyan érdemi mintázatok kirajzolódása, melyeknek köszönhetően minden új fázisban újabb kutatási kérdések és fókuszpontok válnak meghatározhatóvá.

5. Egy kvalitatív jellegű kutatás folyamatosan változik, még a lefolytatott „pilotvizsgálat” ellenére is állandóan s elöre nem tervezhető módon gazdagodik az egészen apró részletekig. Ezért a kulcsadatközlőimmel történő beszélgetések hatására folyamatosan átalakítottam az interjúk kérdéssorát $\mathrm{s}$ az interjúfelvételek módját, így egyre céltudatosabban idomultam a befogadó környezet - kutatásom szempontjából kardinális pontjaihoz.

2016 augusztusa és novembere között végeztem intenzív kutatási tevékenységemet, abban a gyermekothonban, ahol már 2015 októbere óta önkéntes feladatokat látok el, így megfigyelöként és kutatóként is egyaránt könnyen beilleszkedtem e mikroközösségbe. Vizsgálatom céljaként a gyermekotthonban élő fiatalok testmódosítási szokásainak feltárását jelöltem meg, kiemelkedő figyelmet szentelve a tetoválásoknak, elsősorban a tetoválások motivációs hátterét, motívumkincsét és azok jelentéseit igyekeztem feldolgozni, de a minták elkészülésének technikai hátterét is vizsgálat alá vontam. Tágabb kontextusban a gyermekotthon mint (szub)kulturális színtér megismerése és elemzése az a terület, melyben vizsgálatom körvonalazódik.

Kvalitatív kutatásom során létfontosságúnak tartottam, hogy beépülő megfigyelést folytassak a fiatalok között. Hiszen anélkül, hogy belülröl megismerném az életformájuk és kultúrájuk működését, nem végezhetnék ilyen mélységű feltáró, leíró kutatást. A 
gyermekotthonban töltött időszak alatt eleget tettem a résztvevő megfigyelést folytató kutatókkal szembeni alapvető elvárásoknak, illetve az egyidejü kívülállásomat és belül állásomat is sikerült reflektáltan megvalósítanom (Letenyei 2005). Tapasztalataimat, élményeimet mint a közösség tagja és mint külső megfigyelő is értelmezni tudtam. Önmagamra is próbáltam úgy tekinteni, ahogy a közösség tagjai külső szemmel figyelnek engem, s ezzel párhuzamosan kutatóként reflektáltam a saját érzéseimre és cselekedeteimre.

A terepmegismerés kötetlen formája mellett merevnek tekinthető az általam használt strukturált interjúfelvétel módszere, melyet a fiatalokkal való beszélgetés során alkalmaztam. A kötött kérdéssor használatára pontosan a korábbi kötetlenség miatt esett a választásom, hiszen a tetoválások kutatása során a fiatalok életének csak egy apró szegmensét szerettem volna feltárni, kevésbé szenzitíven, a témától eltérő narratíváktól mentesen. Mindemellett a gyerekek számára egy újfajta, lelkesítő tapasztalat volt, hogy egy számukra érdekes témáról beszélgethettek egy felnőttel. Számomra egy ugyanilyen újszerü élményt nyújtott, hogy erről a témáról érdeklődhetek, és ök ebben szívesen közremüködnek. Emellett nagyon nyitott vagyok a gyerekek sorsának megismerésére, érzéseik felfedésére. Éppen ezért önmagam kordában tartására is szolgált ez a strukturált interjúforma. A tetováláskultúra megismerésének ily módon korlátozott formája is bővelkedett érzékeny területek s részletes élettörténetek felvételében. A gyerekektől eltérően a közremüködő nevelőkkel és a független tetoválóval félig strukturált interjúkat készítettem, hiszen a nevelők esetében az intézmény és az abban élők hétköznapjainak mélyebb megismerése, míg a tetoválóval folytatott beszélgetésem során saját tapasztalatainak s szakmai ismereteinek alaposabb feltárása volt a cél.

Az interjúfelvételek elökészítése során külön kérdéssort állítottam össze az intézmény szakmai vezetőjének, nevelőinek, tetovált fiataljainak, a gyermekotthon lakóit tetoválónak, illetve egy független tetoválóművésznek. Így a kutatás során a gyermekotthon szakmai vezetője, 4 csoportvezető nevelő, a gyermekotthonban élő 18 tetovált fiatal, 1 őket tetováló személy, illetve 1 független tetoválóművész szólalt meg. A különböző kérdéssorok közös, kardinális eleme a Forbes-féle motivációs lista (Forbes 2001: 779), amely a tetoválások elkészítésének motivációs hátterét hivatott beazonosítani. Tudatában voltam annak, hogy a standardizált módon feltett kérdések eltérő módon hatnak a különböző társadalmi rétegekben (Letenyei 2005), így e kérdéssorok nyelvezetét és stílusát az aktuális adatközlő személyéhez, valamint a bizalmi viszony mértékéhez igazítottam. Charles S. Pierce határozta meg azokat a feltételeket, melyek szükségesek ahhoz, hogy az interjúalany és az interjú készítője között egy közös alap jöjjön létre (idézi Hegedűs 2010: 175). A beszélgetőfeleknek az alábbi kritériumoknak kell megfelelniük:

- Ismerniük kell az alkalmazott nyelvezeteket: kutatásomat egy egyéves önkéntes időszak előzte meg, ezalatt számos szlenget megismerhettem, azonban a kutatási szakaszban is előfordultak olyan kifejezések, amelyeket meg kellett tanulnom annak érdekében, hogy a közös kommunikáció eredményes legyen, így épült be a szókincsembe a 'zaci' mint a gyermekotthon megnevezése.

- Ismerniük kell a nyelvezetek egyetemes jellemzöit és a nyelvezetek használatát: a legtöbb fiatal a Bernstein-féle kategorizálás alapján korlátozott kóddal kommunikál, 
szókincsük általában szegényes, kevésbé kiterjedt, nehezen fogalmazzák meg érzéseiket.

- Közös alapvetö tapasztalatokkal kell rendelkezniük: tény, hogy az interjúk elkészítőjeként egy eltérő társadalmi rétegből érkeztem, ezt azzal ellensúlyoztam, hogy beavattam a fiatalokat saját életem traumáiba, ezáltal közelebb kerülhettem hozzájuk. Megismerték, hogy mégsem akkora a köztünk lévő szakadék, mint ahogy elsőre elképzelték. Mindezek ellenére egyértelmü, hogy nem ismerem testközelből élettörténetüket, de úgy gondolom, hogy közelebb visz ez a tényező a rögzített adatok reális értelmezéséhez.

- Alapvetően tisztában kell lenniük a testbeszédükkel és nyelvükkel: számos esetben előfordult, hogy nonverbális jelzéseimet nem értették vagy nem megfelelően értelmezték (például amikor felsorolták a tetoválásaikat, saját testemen mutattam, hogy mondják ki hangosan, hogy mely testrészükre utal az ,itt és ott”, de gyakorta ezt az információt nekem kellett kiegészítésként elmondanom).

- Kölcsönös bizalom az interjúkészítö és az interjúalany között: mivel a megelöző egy évet csak egy adott csoport társaságában töltöttem, nem volt az egész intézménnyel kialakított bizalmi viszonyom. Kezdetben konkrét információként tálaltam, hogy ki vagyok, mit kutatok és miért kutatom, ebben az esetben azt tapasztaltam, hogy a fiatalok igyekeznek azt mondani, amit hallani akarok, várták, hogy a szájukba adjam a szavakat. Ezt felismerve stratégiát váltottam, ekkor már úgy közelítettem hozzájuk, hogy elmeséltem nekik, hogy számomra nagyon fontosak a tetoválásaim, és mindig segítettek átlendülni életem nehéz szakaszain, és azt szeretném bebizonyítani, hogy ők sem ítélhetők el a tetoválásaik miatt, hiszen az általuk viselt minták igenis komoly jelentőséggel bírnak. A monológom szinte 100 százalékban sikert aratott, amikor viszont mégis volt némi megingás, akkor szívesen megmutattam nekik a saját ábráimat, és azok láttán végleg megtört a jég.

$\mathrm{Az}$ interjúk felvételének ideje alatt csak a kommunikációra koncentráltam, nem jegyzeteltem, kizárólag a kérdezőbiztosi kérdőívet töltöttem ki a beszélgetés alatt. Ennek a hátoldalán szerepelt a Forbes-féle motivációs lista, ezt az interjú végén átadtam az interjúalanynak, és kellő mérlegelés után válaszait magának karikázta be. A kutatási folyamatban csak olyan adatközlökkel dolgoztam, akik önként vállalták az interjút. Minden interjú elején biztosítottam az aktuális beszélgetőpartneremet, hogy a teljes adatfelvétel névtelenül történik (az írás során adatközlőimet álnevek mögé rejtem), illetve bármikor kiléphet az interjúból. Elsőrendü feladatomnak tekintettem, hogy olyan környezetet teremtsek a beszélgetésekhez, amelyben bátran mesélnek magukról, beavatnak életük részleteibe. Előfordult, hogy számomra is megdöbbentő beszélgetések részese lehettem, olyan érzések és történetek kerültek felszínre, melyeket korábban még sohasem meséltek el. Véleményem szerint legnagyobb részben ettől lehet hiteles és megbízható maga a kutatás.

Mégis, mivel az értelmezés a „saját szemüvegemen át” (Hegedűs 2010: 180) történt néhány közös élettapasztalat ellenére -, nincs garancia arra, hogy amit én a fiatalok számára negatív/pozitív élményként tüntetek fel, az az ő szemükben is az, aminek én látom. Számtalanszor megfordult a fejemben az a kérdés, hogy mi értelme, milyen haszna van annak, amit csinálok, amit kutatok. Mindig arra jutottam, hogy a probléma, amit felvetek, sokkal 
komplexebb, mint egy tetováláskultúra-kutatás, sokkal mélyebb, mint a motívumok fejtegetése. És pont e mélység és komplexitás miatt egész kutatásom alatt kétségek gyötörtek: vajon meg tudom-e érteni, tudom-e jól értelmezni a vizsgált jelenségeket? Összességében úgy gondolom, képes voltam a felmerülő nehézségek ellenére is átlátni az előttem álló rendszert, $\mathrm{s}$ kézzelfoghatóvá tudtam tenni a felém áramló információrengeteget.

Úgy gondolom, hogy a kutatásom e speciális téma határain túl is számtalan módon és helyen felhasználható:

1. A kutatás egésze közvetlen alapot jelent az ezen a terepen végzendő további kutatásoknak.

2. Egy adott szubkultúra (és a beletartozó egyének) müködési mechanizmusainak, mozgatórugóinak megismerése a hasonlóságok és a különbségek tudatosítása révén segíti más hasonló szubkultúrák megértését.

3. A kutatásmódszertan és a kutatói önreflexió részletes leírása módszertani segítséget nyújthat különféle szubkultúra-, ifjúságkultúra-, illetve egyéb szociálpedagógiai vizsgálatokat végző kutatók számára.

4. Az otthonban nevelkedő gyerekek, fiatalok társadalmi integrációja kiemelten fontos társadalmi cél. Kutatásom és az ehhez hasonló kutatások nyomán létrejövő megismerés és megértés reményeim szerint hozzájárulhat a jelenleginél sikeresebb integrációs folyamathoz.

\section{Kutatásom terepe: a gyermekotthon ${ }^{3}$}

Az 1997. évi gyermekvédelmi törvény értelmében „a gyermekotthon otthont nyújtó ellátást biztosít az ideiglenes hatállyal elhelyezett, az átmeneti és a tartós nevelésbe vett gyermek számára". ${ }^{4}$ Azokkal a gyerekekkel találkozhatunk itt, akik bántalmazás áldozatául estek, illetve akiknek családi körülményei nem megfelelők, s ennek okán a család- és gyermekvédelmi központ indítványozza családból való kiemelésüket.

\section{Az intézményi rendszerröl $1^{5}$}

Magyarországon jelenleg több mint 23 ezer gyermek él a szakellátási rendszerben. Közülük csupán 13 ezer gyermek került nevelőszülőknél elhelyezésre, a további 10 ezer fiatal gyermekotthonokban tölti mindennapjait. Átmeneti nevelésről akkor beszélünk, amikor a szülő mindaddig elveszíti gyermeke felügyeleti jogát, amíg a (kiemelést okozó) kedvezőtlen családi viszonyokat helyre nem állítja. Amennyiben ez megtörtént, a gyermeket visszagondozhatják a családjába, s a szülö újra gyakorolhatja jogait. Tartós nevelésbe vételre pedig akkor kerül sor, ha a gyermek szülei elhaláloztak, és a továbbiakban nincs felügyeletet gyakorló szülője, illetve ha a bíróság mind a két szülő felügyeleti jogát felfüggesztette. Ebben az esetben hazagondozásra nincs lehetőség. Hazánkban azonban az átmeneti nevelés

\footnotetext{
3 A szakirodalomra és a törvényi cikkelyekre nem hivatkozott részek a kulcsadatközlöi interjúk alapján készültek.

${ }^{4}$ 1997. évi XXXI. törvény a gyermekvédelemröl és a gyámügyi igazgatásról.

${ }^{5} \mathrm{Az}$ intézményi rendszerről és a gyermekvédelmi gondoskodásban élő gyermekek helyzetéről és megítéléséről bővebben Lőrincz 2017 b.
} 
jelenségét ritkán értelmezik átmenetiként. A legtöbb esetben a gondozásba vett gyermekek egész gyermekkorukat a szakellátási rendszerben töltik (az átlagot tekintve minimum 5,4 évet) (Boytha 2015).

A gyermekvédelmi törvény 2014-es módosítása ígéretes változásokkal kecsegtetett: a 12 év alatti gyermekek - a speciális esetek kivételével - csak nevelőszülöi gondoskodásban kerülhetnek elhelyezésre, illetve a nagy gyermekotthonokat felszámolják (ezzel csökkentve a gyermekek és fiatalok hospitalizációjának kialakulási esélyét), és megkezdődik az intézményes nevelésben élő gyermekek családokhoz való kiutalása. Emellett a törvény megszüntette az átmeneti és a tartós nevelés fogalmát, ezáltal 2014-től az ideiglenes hatályú elhelyezés, valamint a nevelésbe vétel fogalmainak használata a megfelelő. ${ }^{6}$ Persze az elnevezés módosítása nem volt elegendő ahhoz, hogy az állapotok is megváltozzanak.

Az általam vizsgált gyermekotthon jelenleg 103 fönek nyújt teljes ellátást, ebből 66 fiatal „elérhető”, tehát a gyermekotthonban tartózkodik ${ }^{7} .29$ fö van szökésben (bejelentés nélkül ismeretlen helyre távozott, határozatlan időre), illetve 8 fö tölti büntetését valamely büntetés-végrehajtási intézményben. A gyermekotthon megszakítás nélküli munkarendben alapszolgáltatásként biztosít lakhatást a gondozott gyermekek számára, szükség esetén a fiatal felnőtteknek utógondozói ellátást nyújt. ${ }^{8}$ Jelen intézményben 11 utógondozott fiatal él. Az életkori megoszlás tekintetében az intézmény lakóinak átlagéletkora 15 év, a legalacsonyabb életkorú gyermek jelenleg 7 éves, míg a legidősebb a 24. életévében jár.

E gyermekotthonban a gyermekek maximum 12 fös csoportokban élnek, nemi és életkori differenciálástól mentesen. Az intézmény 3 nagyobb otthonból áll, melyek további 3 csoportra oszlanak, így 8 csoportot a gyermekotthon falain belül, és egy kizárólag árva gyerekekböl álló csoportot lakásotthoni körülmények között helyeztek el. A csoportok lakótere átlagosan egy nappaliból, egy konyhából, egy fürdőszobából és 3-4 hálószobából áll, szobánként 2-4 gyermek kerül elhelyezésre. Utógondozottak esetében van lehetőség a csoporton belül egyszemélyes, zárható szobák kiosztására is.

Azonban azon túl, hogy a törvényi rendelkezés pontosan és határozottan rögzíti a gyermekek rendszerben elfoglalt helyét és gondozási folyamatukat, tudnunk kell, hogy a gyakorlatban ez a hatékony, gördülékeny elképzelés nem - vagy csak töredékesen - valósul meg. A külvilág számára is bővelkedik szemmel látható problémákban.

Az intézmény szakmai vezetője az alábbi problémákat tekinti a legsúlyosabbaknak: ${ }^{9}$

- $\quad$ A gyermek kiemelése csak az utolsó utáni pillanatban történik meg, akkor, amikor nevelési szempontból a legnehezebb „hozzányúlni” a gyermekhez, hiszen a kamaszkor viharos időszakát éli. Ennek kompenzálására nincs elég szakember a családsegítésben, nincsenek kontroll alatt a családok, 10-12 éves kor alatt olyan normák rögzülnek a gyerekekben, amelyeket az otthonban töltött 2-4 év alatt lehetetlen megváltoztatni.

\footnotetext{
${ }^{6}$ 2014. évi CI. törvény a gyermekek védelméröl és a gyámügyi igazgatásról szóló 1997. évi XXXI. törvény módosításáról.

${ }^{7}$ 2016. augusztus 10 -i adat.

${ }^{8}$ A gyámhivatal a fiatal felnőtt kérelmére elrendeli a további utógondozói ellátását, ha létfenntartását önállóan biztosítani nem tudja, nappali tagozaton tanulmányokat folytat, illetve szociális bentlakásos intézménybe felvételét várja (1997. évi XXXI. törv.).

${ }^{9}$ A rögzített „problémákat” saját tapasztalataimra, illetve kulcsadatközlőim elmondására alapozom.
} 
- A rendszer túlzottan bürokratikus. Amíg a rendszeren áthalad egy személyes anyag, tehát mire a szakértő megvizsgálja, mire összeül az elhelyezési csoport, mire a gyámhivatal dönteni tud, mire a kirendelt gyermekvédelmi gyám gondoskodni tud a gyermek beszállításáról, mire elökészíti a helyét az intézmény, addigra eltelik minimum 3 hónap, esetenként 1 év. Ez idő alatt a gyermek átmeneti státuszban van, megszokja, hogy a tetteknek nincs következménye, nincsenek szabályok. Erről a pontról visszaszocializálni arra, hogy reggel felkeljen, iskolába menjen, és hogy egy napirend szerint éljen, szinte lehetetlen feladat.

- „Annyira alulfizetettek a rendszerben a pszichológusok és a fejlesztőpedagógusok, hogy egy kezdő pszichológus nem kötelezi el magát egy gyermekotthonbeli munkahely mellett, inkább szakmájától független multinacionális cégeknél helyezkedik el, ahol 1-2 hónap alatt megkeresi azt az összeget, amit az otthonban kb. 1 év alatt teremthetne elő."10 Gyermekotthononként 1 pszichológussal számolhatunk, ami intézményi tekintetben összesen 3 szakembert jelent, ez a szám nem elegendő a gyermekek kezelési igényeinek kielégítésére.

- $\quad$ Sokszor kerülnek a gyerekek az intézmény falai közé ,álszakértői” véleménnyel. Nem tudják megfelelő helyen elhelyezni őket, mert speciális ellátást igényelnek. A gyerekek nagy része ilyen. Speciális a rendszerben, aki antiszociális, szerhasználó, halmozott büncselekményeket követett el. Öket speciális intézménybe kellene elhelyezni, belső iskolával, fejlesztő foglalkozásokkal, terápiás csoportokkal. ${ }^{11}$ Magyarországon kevesebb mint száz speciális férőhely került kialakításra, így a legtöbb speciális ellátást igénylő gyerek olyan gyermekotthonba kerül, ahol a nem speciális gyermekek nevelésére képzett nevelők látják el a velük kapcsolatos feladatokat.

Mint láthatjuk, a legelemibb szinten jelentkeznek olyan problémák, melyek a gyermekotthon napjainak minden pillanatát áthatják s megnehezítik. Mindezek mellett az intézmény komoly anyagi nehézségekkel is küzd. Az épületet évek óta nem újították fel, mind külső, mind belső állapota elrettentő körülményeket sugall. A családjukat nélkülözni kényszerülő gyermekek számára nem nyújt bizalomgerjesztő látványt, s leginkább egy régi börtönre emlékeztet. A csoportok a gyerekek saját kezűleg készített dekorációitól válnak némileg otthonossá, de nem sugároznak melegséget.

\section{A védelembe vett gyermekekről}

„, Gyakorlatilag ide várt gyerek nem érkezik. Úgy még én nem kaptam gyereket, hogy várták, szerették volna, fel akarta volna nevelni a szülö, csak kisiklott a házassága vagy az élete egy hitel miatt, s ezért kiemelték a gyerekét. Egyébként sem várták. Persze ezek a gyerekek azok, akik csecsemökorban is bántalmazottak, akit megrázunk, akit félre lehet dobni,

\footnotetext{
${ }^{10}$ Részlet az intézmény szakmai vezetőjével készített interjúból.

${ }^{11}$ A beilleszkedési, magatartási vagy tanulási zavarokkal küzdő gyermek speciális gyermekotthona legfeljebb 15 gyermek gyermekotthont nyújtó ellátását, gondozását, habilitációját és rehabilitációját biztosítja (1997. évi XXXI. törv.).
} 
akinek jó a cukros víz"12 - egészíti ki korábbi gondolatát az intézmény szakmai vezetője, s e tényezőket tekinti az aktuálisan fennálló problémák gyökerének.

Árnyalja, változtatja a képet, ha megvizsgáljuk a TASZ (Társaság a Szabadságjogokért) álláspontját is. Eszerint Magyarországon jelenleg több mint 23 ezer gyermek él a szakellátási rendszerben. ${ }^{13}$ Bár a gyermekvédelmi törvény szigorúan tiltja, hogy anyagi okok miatt emeljék ki a gyermeket a családjából, napjaink gyakorlata mégis azt mutatja, hogy számos esetben a nem kielégítő anyagi körülményekre hivatkozva választják szét a családokat. Bármi is legyen a szétválasztás oka, a családtól való elválás sok esetben sokkal nagyobb kárt tesz a gyermekekben, mint azt a rendszer képviselői gondolnák. Mindnyájan tudjuk, hogy a család - milyenségétől függetlenül - meghatározó szerepet tölt be az ember életében. A család:

- Az az elsődleges szocializációs színtér, mely a legkorábbi életszakasztól hatást gyakorol az egyén fejlődésére. Itt tölti csecsemő- és kisgyermekkorát, mely az élet legfogékonyabb és legintenzívebb periódusa.

- A családban kialakult érzelmi kötelékek erőssége olyan hosszan tartó hatást gyakorol az egyénre, melynek köszönhetően egy életen át hordozott érzelmi és viselkedési modellek épülnek be a személyiségébe.

- Közvetítő szereppel bír az egyén és a társadalom között, annak értékrendjét, normáit személyes példa által közvetíti, a társadalmi értékrendszert beépíti a személyiségbe. Ezáltal az egyén képes lesz beilleszkedni a társadalomba, képes lesz önmaga megvalósítására (Bagdy 1995).

A szocializáció hosszas folyamatában a család az elsődleges modell szerepét foglalja el, a szülő az a minta, melyet a gyermek minden esetben követ. A szülök társadalmi helyzete, társadalomhoz való viszonya, nevelési szokásai, a megteremtett szociális háttér és az abból fakadó motivációs tényezők mind szerepet játszanak a gyermek személyiségének formálódásában (Bagdy 1995). Ezen szempontok megvizsgálása elengedhetetlen, mikor a gyermekek nevelésbe vételéről, gyermekotthonba kerüléséröl értekezünk. Nem szükséges hosszas kutatást végeznünk ahhoz, hogy lássuk, a gyermekvédelmi intézménybe került fiatalok családjának nagy része nem tudta ellátni alapvető funkcióit, nem tudott támogató rendszerként müködni.

Eric Berne (1997) szociálpszichológus fogalmazta meg azt a gondolatot, hogy minden gyermek egy „,sorskönyvvel a fejében” jön a világra. Ennek értelmében meghatározza egész életüket, hogy várt vagy nem várt gyermekként érkeztek, milyen nevet kaptak, milyen módon élnek. Saját élettörténetük alakítása a gyermekkorban kapott szülői üzenetek függvényében történik. Kutatási terepem 103 lakójának többségéröl elmondható, hogy születése nem hozott felhőtlen boldogságot a családba. Mi sem bizonyítja ezt jobban, mint 18 testvérsor gyermekotthonban való nevelkedése. Ezek a testvérsorok, melyek tagjait együtt vagy sorozatosan emelték ki a családjukból, az intézményben élő fiatalok mintegy 50 százalékát teszik ki, vagyis a gyerekek felének legalább egy testvére az otthonban él.

A testvérsorok kezelésének problémája több formában is megjelenik. Számolhatunk olyan esettel, mikor például egy 11 gyermekes család minden gyermeke - nem azonos időben

\footnotetext{
${ }^{12}$ Részlet az intézmény szakmai vezetőjével készített interjúból.

${ }^{13}$ A TASZ 2016-os adatai alapján (www.tasz.hu).
} 
- a gyermekotthon lakójává válik. Azonban az sem ritka, hogy a többgyermekes családokból egyes gyermekeket kiemelnek, de a testvérek a családban maradnak. Továbbá előfordul, hogy az édesanya a gyermeke(i) nevelésbe vételét követően újabb gyermeke(ke)t szül, aki(k)nek igyekszik megteremteni a megfelelö körülményeket, de elvett gyermekei hazagondozására nem törekszik. Nem lehet megítélni, hogy melyik helyzet a legsúlyosabb, hiszen minden esetben a családok szétszakításának s a szülö-gyermek viszony rendellenes müködésének fájdalma áll a középpontban.

Ahogy az a fejezet elején idézett interjúban elhangzott, a családból való kiemelés egyik gyakori oka a csecsemőkortól fennálló bántalmazás, ami - a megfelelő időben történő segítségnyújtás hiányában - az egész gyermekkoron átívelhet. Azok számára, akiknek a gyermekbántalmazás, elhanyagolás, szexuális erőszak, családi fenyegetettség, megalázás, kihasználás csak ritka büncselekményként volt ismert, ami mindig valahol máshol és valaki mással történik, nagyon nehezen fogadható el, hogy egyre több ilyen eset válik ismertté, s könnyüszerrel fordulhat elö az ő környezetében is (Herczog 2007). Az eseményekkel együtt járó traumatizációnak számos fajtáját különíti el a szakirodalom, de jelen esetben az ún. interperszonális - vagyis ember okozta embernek - traumatizáció a domináns (Kuritárné 2015), hiszen leginkább a családon belül a szülők fordulnak saját gyermekeik ellen. Ha egységes definíciót keresünk a gyermekbántalmazás fogalmára, a legkielégítőbbnek a WHO által használt meghatározás bizonyul: ,a gyermek bántalmazása és elhanyagolása (rossz bánásmód) magában foglalja a fizikai és/vagy érzelmi rossz bánásmód, a szexuális visszaélés, az elhanyagolás vagy hanyag bánásmód, a kereskedelmi vagy egyéb kizsákmányolás minden formáját, mely a gyermek egészségének, túlélésének, fejlődésének vagy méltóságának tényleges vagy potenciális sérelmét eredményezi egy olyan kapcsolat keretében, amely a felelősségen, bizalmon vagy hatalmon alapul" (Hegedűs, Pintyi 2008: 5). Ennek értelmében a gyermekbántalmazás négy nagy csoportját különíthetjük el:

1. érzelmi abúzus,

2. fizikai bántalmazás,

3. szexuális bántalmazás,

4. elhanyagolás.

Az érzelmi abúzus a gyerek érzelmi bántalmazása, amelynek alapvető hatása, hogy a gyermek szerethetetlennek, értéktelennek érzi magát. Ez fokozható a fejlettségi szintnek nem megfelelő bánásmód, a megfélemlítés, a kizsákmányolás és a fenyegetés eszközeivel. E felsorolás gyakran kiegészül fizikai bántalmazással, olyan szándékos vagy gondatlanságból elkövetett cselekedettel, amely a gyermek fizikai sérüléséhez, súlyos esetben halálához vezet, ilyen például a büntetés erőszakos formái, a kínzás, valamint a fenyítés. E gyakorlatokkal rokon a bántalmazás szexuális formája, amely során szexuális aktivitásba vonnak be egy gyereket, aki sem életkoránál, sem fejlettségénél fogva nem érett erre. Ebbe a körbe tartozik a molesztálás, a fizikai kapcsolat, illetve pornográf tartalmak megtekintésébe való bevonás is. E három típus mellett kevésbé megrendítőnek s számottevőnek hathat az elhanyagolás, mint a bántalmazás negyedik válfaja. Nincsenek sebek, nincsenek kék foltok. A közvélekedés számos esetben úgy tartja, hogy a szegénység a társadalom perifériáján való életforma velejárója, tehát elsősorban anyagi eredetü, ha a gyermek elhanyagolásnak van kitéve. Ez az állapot egy olyan tartós 
helyzet, melyben hiányzik a gyermek felé irányuló szeretet, a gondoskodás, elmarad a táplálás, illetve hiányoznak a gyermek fejlődéséhez, alapvető szükségleteinek kielégítéséhez elmaradhatatlan tárgyi feltételek (Herczog 2007; Kuritárné 2015; Boytha 2015).

Bár kutatásom nem vonja vizsgálat alá a gyermekek családból való kiemelésének okát, illetve szocioökonómiai státuszát, mégis a nevelőkkel készített interjúimból építkezve kerek képet alakíthattam ki az itt élö fiatalok gyökereiröl. Ennek okán fontosnak tartom, hogy a bántalmazás különböző formáit kutatási terepem s alanyaim bemutatása során feltüntessem, hiszen ezen ismeretek által realizálódik, hogy milyen traumatikus hatások érték azokat a fiatalokat, akikre a ,jobb élet” csak egy gyermekotthonban talált.

Ha az ismertetett körülményeket a Maslow-i piramis szükségleti szintjeire levetítjük, azt mondhatjuk, hogy míg a fiziológiai szükségletek kielégítése rendszerszinten megtörténik mert meg kell, hogy történjen, hiszen étlen, szomjan s fedél nélkül nem élhetnek a gyerekek -, addig a biztonság és a védelem már sok esetben elérhetetlen magaslatokban van. A biztonsági szolgálat kialakítása, ami elsősorban az intézmény értékeit védi s nem a fiatalokat, valamint az ablakrácsok és a kerítés nem biztosítanak védelmező környezetet számukra. Biztonságérzetet egymásnak nyújtanak, a legtöbb esetben a testvérsorok támogatják egymást, illetve a „testvérnek fogadottak”, olyanok, akikkel a gyermekotthonban ismerkednek meg. Számos atrocitás éri őket az intézmény falain belül s azon kívül egyaránt. A ,hazavezető úton" a lányok gyakran kapnak prostitúcióra csábító ajánlatokat, a fiúk pedig észrevétlenül keverednek verekedésekbe. Azonban míg a fiúk könnyen kezelik ezeket a helyzeteket, többségében nem riadnak vissza a megpróbáltatásoktól, addig a lányok, ha lehetőségük engedi, csoportosan közlekednek, még az intézmény kapuja elött is félnek egyedül. Mint látható, biztonságot elsősorban egymás társaságában éreznek, $\mathrm{s}-\mathrm{a}$ következő szint - a szeretet és az összetartozás érzése is csupán csoportszinten valósul meg. Az önbecsülés kialakulása és az önkifejezés megvalósulása többségük számára még lehetőségként sincs jelen.

Véleményem szerint gyökereik hasonlósága, azonos sorstragédiáik és veszteségeik, az ezekből adódó közös szocializációs tér, valamint a magasabb szükségletek kielégítése iránti (nem tudatos) vágy képes különlegessé tenni ezeket a fiatalokat, egy olyan sajátos szubkultúrával rendelkező közösséget tud kiépíteni, mely a többségi társadalom és a periféria határmezsgyéjén mozog. A többségi társadalom nem hajlandó befogadni e közösség tagjait, hiszen nem képes rájuk erőltetni a standardizált szabályait. Azonban a periféria intézményeihez sem kapcsolhatók (pl. börtönök, javítóintézetek, elmegyógyintézetek), hiszen nem devianciájuk okán kényszerültek közösség alkotására.

\section{Egy sajátos közeg és szubkultúra}

A szubkultúra fogalmi meghatározása az 1960-as évektől zajlik, kiindulópontjának Albert K. Cohen szociálpszichológiai alapokon nyugvó szubkultúra-felfogása tekinthető, amely szerint „szüntelenül megteremtik, újjáteremtik és módosítják a kultúrát, amikor csak az egyének megérzik egymásban a hasonló körülmények által létrehozott hasonló szükségleteket [...] Az effajta szubkulturális rendszer [...] túlélheti a megteremtésében részt vett egyéneket, de csupán amíg kielégíti a megteremtők utódainak szükségleteit” (Cohen 1969: 279). E meghatározás mellett feltünteti a szubkultúrák müködésének kísérő jelenségeit, mint a tagok 
közötti csoportszolidaritás, a csoporttagok fokozott interakciója, a csoport hangsúlyozott különállása, illetve, hogy az új csoportban a tagok státusza (elismertségük, megítélésük) átalakul a korábbi csoportban elfoglalt helyükhöz képest. Megjelenésekor e fogalom a normális-deviáns kettősségben értelmeződött: a szubkultúra-deviancia a társadalmi normákhoz képest a bünözéssel és az erkölcstelenséggel azonosítva jelenik meg (Cohen 1969).

Hogyan képeződik le ez a megállapítás a gyermekotthon kultúrájában? Ahogy azt már korábban bemutattam, a definíció elemeinek megjelenéséhez nem fér kétség. Hiszen a hasonló körülmények által létrehozott hasonló szükségletek kielégítésének igénye a legelemibb tartópillére a gyermekotthon közösségének. A tagok közötti csoportszolidaritás tisztán látható, testvérekként tekintenek egymásra, tudatában vannak csoportjuk valóságával, azzal, hogy ők elsősorban odatartoznak - a család, mint elsődleges csoport híján -, kiállnak egymásért és a csoport egészéért. Ebbe a kategóriába sorolható a „spiclik” kirekesztése: azokat a fiatalokat, akik az átlagosnál jobb viszonyban vannak a nevelőkkel, illetve akik információkat szivárogtatnak ki társaikról a nevelök, a vezetőség felé, közutálat tárgyává teszik. Ez a tényező szervesen összekapcsolódik a tagok közötti fokozott interakcióval. Mivel elsősorban egymásra támaszkodhatnak, egymástól kérhetnek segítséget, pénzt, cigarettát, egymással oszthatják meg gondjaikat, és az ,árulók” kiszürése, majd tudatos kirekesztése is csak kommunikáció útján mehet végbe. A csoport különállásának hangsúlyozása a közös kultúrán belül szerveződött csoportok szintjén is megragadható, például nem engedik be más kisebb csoportok lakóit a saját lakóövezetükbe, territoriális alapon védelmezik azt, ami az övék. Az otthon lakossága, mint egy nagy csoport, területileg is elkülönítettnek bizonyul, hiszen a város egy félreeső részén helyezkedik el. Számos gyerek jár ugyanazon iskolába, bár különböző szintű osztályokban tanulnak, a szüneteket gyakran együtt töltik, problémáikkal az iskolán belül is egymáshoz fordulnak. Nem egyedi eset, hogy a tanárok hátrányos megkülönböztetésben részesítik a „gyivis” gyerekeket. A legtöbb gyerek tudja, milyen érzés kirekesztettnek lenni, milyen a közösségben megbélyegzettként jelen lenni. Kihez fordulnának hát, ha nem egymáshoz? Mi erösítené bennük azt, hogy a megküzdésnek ne ezt az elkülönülési módját válasszák? Ahogy mindannyiuknak meg kell vívniuk a hierarchiaharcot az iskolába való bekerüléskor, ugyanúgy az intézményben való elhelyezést követően minden fiatal átesik a státuszkeresés időszakán. El kell, hogy fogadtassa magát egy már összeszokott közösségben, el kell érnie, hogy emberszámba vegyék a többiek, s amint ez sikerült, hagynia kell, hogy a többség elhelyezze őt a hierarchia egy bizonyos szintjén. Hiába volt az előző otthonban vagy büntetés-végrehajtási intézményben egy domináns szereplő, előfordulhat, hogy az új közösségben a legalacsonyabb szinten megreked. ${ }^{14}$

A fiatalokkal töltött idő során bizonyosságot nyerhettem a felöl, hogy nem egy tudatosan kiépített kulturális közösségről beszélünk, hanem egy spontán szerveződő, folyamatosan megújuló, „tagcseréken” áteső csoporttal állunk szemben, mégis - ahogy Cohen megállapította - egy jól strukturált, belső szabályszerüségekre épülő, törhetetlen összetartó erővel bíró, szubkulturálisnak tekinthető térben élnek. Ennek az összetartozásnak egy kiiktathatatlan kifejezőeszköze a tetoválások megjelenése a közösségen belül. A tetoválások

\footnotetext{
${ }^{14}$ Kutatásom során nem végeztem mélyfúrást a szubkultúrát kísérő jelenségek megvalósulását illetően, illetve a bünözésre, devianciákra vonatkozó adatok összesítésére, összevetésére sem terjesztettem ki vizsgálatomat. E kérdéskör vizsgálata egy következö kutatásom témája lehet.
} 
készítésének módját, motivációját, motívumkincsét vizsgálva azt mondhatjuk, hogy a korábban már hangsúlyozott közös gyökerek ezeket a testmódosító eljárásokat is összekötik. $\mathrm{S}$ ha módszeresen felmérjük, hogy miket hordoznak a testükön ezek a fiatalok, térképet kaphatunk a múltjukról, a fájdalmaikról, a vágyaikról, a jövőjükről és önmagukról.

\section{A tetoválás - Testünk mint kulturális tárgy}

Az egyén szociális identitással rendelkezik, megpróbálja testi sajátosságait nyelvként hasznosítani, s a testmódosítással nyelvi eszköztárát igyekszik változatossá, kifejezőbbé alakítani. Ez egy bonyolult folyamat, a szocializáció során a személyiség először magára ölti a csoportidentitás jeleit, majd ezeket individualizálni kezdi, s a csoporttól kapott folyamatos visszajelzések hatására elindul önmaga formálásának útján. Így a külső egyszerre két funkciót tölt be: jelzi a csoporthoz tartozást és jelzi az egyéniséget (Szendi 2009). Az imént „nyelv”ként meghatározott, kommunikációs szerepet betöltő elemet jelen esetben a tetoválásokra korlátozom. Nem kívánok a tetoválások kultúrtörténeti sajátosságairól értekezni, csupán azt szeretném kiemelni, hogy az archaikus időktől napjainkig a tetoválások motivációja, megítélése folyamatosan változott. Manapság bizton állíthatjuk, hogy a tetoválások egyre nagyobb népszerüségnek örvendenek, s a korábban szubkultúrákra jellemző, deviáns magatartásformát jelölő testmódosítási eljárások ma már teret hódítanak a társadalom minden szintjén.

A kutatók kezdetben a tetoválások vizsgálatát börtönökben vagy pszichiátriai intézetekben végezték, és mivel a tetoválásviselést eleve devianciaként definiálták, az így kimutatott eredmények csupán az adott közösségben voltak érvényesek, és nem váltak kiterjeszthetővé a társadalom egészére (Szendi 2009). Mára a tetoválás jellemzően maga mögött hagyta stigmatizáló jelentését, kutatásom során ennek kiemelésére is komoly hangsúlyt fektetek. Bár kutatási alanyaim egy viszonylag zárt közösség tagjai, nem deviáns magatartásukból eredendően kerültek az intézménybe, így nem válik indokolttá a deviancia és a tetoválás fogalmi kereteinek összemosása.

Ahogy Szendi Gábor pszichológus mondja, ,a tetoválások jelentésében benne rejlik a fájdalom elviselése, a közmegítélés vállalása, a maradandóság elfogadása. Tetováltnak lenni mindezt jelenti." (Szendi 2009: 26) Testünket mint saját kultúránk kifejezésének eszközét használni nem új keletű felfogás. Bőrünket, múltunk történetének vásznaként felhasználni, már annál inkább tekinthető modern gondolkodásnak. Korábban a társadalomból elhurcolt, kirekesztett egyének (elsősorban börtönviseltek) eszköze volt a „bőrvászon”, azt a célt szolgálta, hogy a régi életük pillanatait az elzárt világban is magukénak tudhassák (Fliegauf 2014). A megpróbáltatások hatására az emlékek elkopnak, márpedig egy izolált, erőszakkal kialakított közösségben, ahol a magántulajdon ismeretlen fogalom, ott az ember csak az emlékeit tekintheti magáénak. Ezek a bőrbe varrt képek egy életen át megmaradnak, s még ha a köréjük épült történetek el is halványulnak, a motívumok akkor is jelzik majd, hogy az egyénnek felesége, családja, munkája, élete volt. A tetoválás valami megbízhatóan állandó. Ami az emberből fakad, amibe bele lehet kapaszkodni. Egyfajta ősbizalom, mint Odüsszeusznak a hajóárboc, amihez kikötötte magát, védekezve a szirének ellen. Egyfajta ősbiztonság. Kapaszkodás (Spitzer 2009). 
A tetoválásokat többféle módon lehet kutatni: a) kultúrtörténetileg (mert ösidőkre visszanyúlik); $b$ ) etnográfiailag (a mai élő kultúrák összehasonlításával); $c$ ) történeti-lélektani szempontból (melyik korszakban mit jelent) és $d$ ) funkcionális módon, amikor is arra kívánunk választ adni, hogy milyen szociálpszichológiai és kommunikációs jelentése van a feltetovált jeleknek (Buda 2009). Dolgozatomban a funkcionalista megközelítés szempontjából vonom vizsgálat alá a gyermekotthonban élö fiatalok tetováláskultúráját. Egy szűkülő perspektívában kívánom felépíteni eredményeim bemutatását.

A struktúrát tekintve egy globális, társadalmi szinten müködő tetováláskultúra van érvényben, mely meghatározott szabályszerüségek szerint, anatómiai, technológiai, gazdasági ismeretek birtokában stabilizálódik. Ennek alárendelt válfajaiként vannak jelen az egyes intézmények, szubkultúrák sajátos tetoválásvilágai, melyek többségében szakszerü ismeretek hiányában, de sajátos „szakmai repertoár” kialakításával végzik testmódosító eljárásaikat. Ezeknek a világoknak az építőkövei pedig maguk az egyének, akik bizonyos motivációktól vezérelve alávetik magukat a visszafordíthatatlan beavatkozásoknak. Hogy mitől válik egy tetoválás felhelyezése megmásíthatatlan bélyeggé, egy örök társsá, azt - a lelki tényezőktől elvonatkoztatva - maguk az anatómiai tények mutatják meg.

\section{A megkérdezettek egyes alapadatai}

A vizsgálatban 14 és 23 év közötti fiatalok vettek részt. Adatközlöim elsö tetováltatása átlagosan 14 éves korra tehető. A fiatalok legnagyobb százaléka a gyermekotthon falain belül készítteti el első tetoválását, kevesen kerülnek be már tetováltként. Azonban akik mégis így jutnak az intézménybe, azok első tetoválása is hasonló körülmények között, leggyakrabban a család körében készült.

Jelenleg átlagosan 5 tetoválással bírnak a vizsgált fiatalok, ennek szórása 1-től 10-ig terjed. A kutatásom során összesen 70 tetoválást néztem meg, fényképeztem le, ebből 58 a fiúkon, 12 a lányokon található.

A mintában szereplő egyének jelenlegi iskolai foka 5. és 12. évfolyam közé tehető. A fiatalok többsége általános iskolai, illetve szakiskolai tanulmányokat folytat. Azok az általános iskolák, ahová az intézmény be tudja iskolázni a családból kiemelt gyermekeket, olyan szociokulturális közeget nyújtanak, ahol nem számítanak kirívónak a gyermekotthonban élö gyerekek. Gyakran elöfordul, hogy olyan hátrányos helyzetü, illetve halmozottan hátrányos helyzetü gyerekközösségbe járnak, ahol bár családjukban nevelkedő, mégis igen nehéz sorsú, mélyszegénységben élő gyerekek tanulnak. Az általános iskolát követően - aki folytatja tanulmányait, hiszen gyakorta nem sikerül elvégezniük 8 év alatt az iskolát, így a tankötelezettségi korhatárt sok esetben 8. osztályosként érik el - szakiskolába kerülnek a fiatalok. Itt többségében törekszenek arra, hogy minél rövidebb idő alatt elvégezhető képzésben vegyenek részt. Egyrészt, hogy ne kelljen hosszú évekig iskolába járniuk, másrészt, hogy hamarabb elhagyhassák a gyermekotthont.

Rendörségi ügyek a megkérdezettek felénél jelentek meg, saját bevallásuk alapján átlagosan 15-16 rendőrségi ügy jut egy före, egytől egészen akár ötvenig. A leggyakoribb atrocitás a lopás, a garázdaság és a verekedés, de graffitizést, betörést is találunk a listán. Ezek elsősorban fiúk élettörténeteiből származó adatok, a lányok esetében inkább a kábítószerhasználat, illetve a tanúskodás kötődik a rendörséghez. 
Káros szenvedélyek tekintetében a legmeghatározóbb a dohányzás, ez adatközlőim 100 százalékát érinti. A kábítószer-használatra vonatkozóan a vizsgált fiatalok két táborra oszthatók: a „nem” és a „már nem” használók, senki sem vallotta magát aktuálisan droghasználónak. A megkérdezettek közel fele hagyott fel a kábítószerrel 1-2 év rendszeres használat után. A legmeghatározóbb a „füves cigi” élvezete volt. A fiatalok alkoholfogyasztási szokásaira leginkább az „alkalomadtán” kifejezés jellemző.

Elmondható, hogy a tetoválást viselők között kevesebb mint 50 százalékos arányban jelenik meg a törvénnyel való szembekerülés, illetve a komolyabb szenvedélyek előfordulása. Ennek a területnek a vizsgálatát egy következö, kifejezetten a devianciákra fókuszáló kutatásomban tervezem. Ebből a százalékos adatból kiindulva nem vonható le következtetésként a deviáns magatartás mint általánosítás. ${ }^{15}$

\section{2. „Így nem fáj annyira, amit nem bírok elviselni” - A tetoválások motivációs háttere}

A tetoválás a személyi müvészet, azon belül pedig a testművészet kategóriájába sorolható, melynek elsődleges célja az önkifejezés. A testmüvészetet - módozatait tekintve két részre oszthatjuk, ezek a mozgatható (változtatható) és a nem mozgatható (meg nem változtatható) díszítések.

A mozgatható díszítések körébe tartozik például a ruházat, az ékszerek, a smink, a hajviselet. Míg a nem mozgatható elemek olyan díszítési formákat jelölnek, melyek a test állandó módosulásához vezetnek. Ilyenek a fül átszúrása és tágítása, a fogak kihegyezése, piercingek behelyezése, illetve tetoválások készíttetése is (Bodrogi 1987).

Nem véletlenül nevezzük „személyi” müvészetnek a tetoválást. A személy maga határozza meg, hogy milyen indíttatásból, milyen motivációkból merítve tetováltatja testére azt a mintát, amelyet saját maga választott vagy alakított ki. Ezzel személyisége egy darabja kerül a bőrére. Az egyén elsősorban nem a szociális kívánatosságra törekszik, hanem identitását akarja kifejezni (Szendi 2009). Hiszen saját teste az „abszolút referenciakeret”, ezzel van lehetősége a szociális és fizikai térbe való beilleszkedésre. A test az ember énképének hordozója, azonosságának, vélemény- és viselkedésrendszerének integrátora (Solymosi 1987). Teste által közvetíti a társadalom számára azt, hogy kinek tartja magát valójában.

A motivációs tényezők együttes feltérképezésével elmondható, hogy sokkal mélyebb rétegei vannak az elkészült tetoválásoknak, mint azt első látásra gondolnánk. A családjukból kiemelt vagy a szüleik által elhagyott gyerekek életében létfontosságú szerepet tölt be, hogy a család, az összetartozás hiányát pótolják. Egyértelmü tehát, hogy a depriváció enyhítése kimagasló szerepet tölt be a felmerülő motívumok esetén. Hiányt szenvednek a szeretetben, a gondozásban, a szükséges szociális ingerekben, a visszajelzésekben, a megerősítésben. Az, hogy milyen módon élik meg ezt a deprivációt, személyenként eltérő. Ennek csupán egyetlen módja a tetováltatás.

Az intézmény falai közt sétálva ez a hely a börtön kopott falait idézi fel az emberben. A fiatalok viselkedése és gondolkodása is számtalanszor ezt az allegóriát tükrözi. Önmagukat

\footnotetext{
${ }^{15}$ Ezzel szemben számos amerikai kutatás azt bizonyítja, hogy a testdíszítéssel rendelkező fiatalok sokkal inkább dohányoznak, fogyasztanak alkoholt, élnek kábítószerekkel, illetve nyugtatók és antidepresszánsok használatában is az élen járnak (Kaldenekker, Pikó 2005: 158).
} 
„elítéltnek” tekintik és az intézményt egy fegyháznak titulálják. Erre a tényre alapozva emelhető be Sykes (1985) azon öt szempontja, melyek a bebörtönzéssel járó megpróbáltatásokat kategorizálják. A csoportokat nem az eredeti formájukban, hanem a gyermekotthon intézményesült rendszerére átalakítva használom. Ezek a következők: a) a családi élettől való megfosztottság; b) a magántulajdontól való megfosztottság; $c$ ) az intimitástól való megfosztottság; $d$ ) az autonómiától való megfosztottság; e) a biztonságtól való megfosztottság (bővebben Lőrincz 2017a).

3. „Itt ezek a kis házikók az intézetet szimbolizálják” - A tetoválások motívumrendszere ${ }^{16}$

Kutatásomból egyértelmüen fény derült arra, hogy a vizsgált intézményen belül egy jól körülhatárolható motivációs bázis és motívumrendszer épült ki az idők során. Két nagy csoportot különítettem el a tetoválások motívumainak tárgyalása kapcsán: a szöveges motívumokat és a figuratív motívumokat. A szöveges motívumokon belül a család, a szerelem, az egység kifejezése, illetve a saját maguk motiválása a leginkább megragadható részterületek. A figuratív motívumok esetén beszélhetünk egyszerü motívumokról, ezek a vallási szimbólumok, a vonalábrák és a nonfiguratív ábrák. Emellett azonosíthatók komplex, összetett motívumok is (1. ábra).

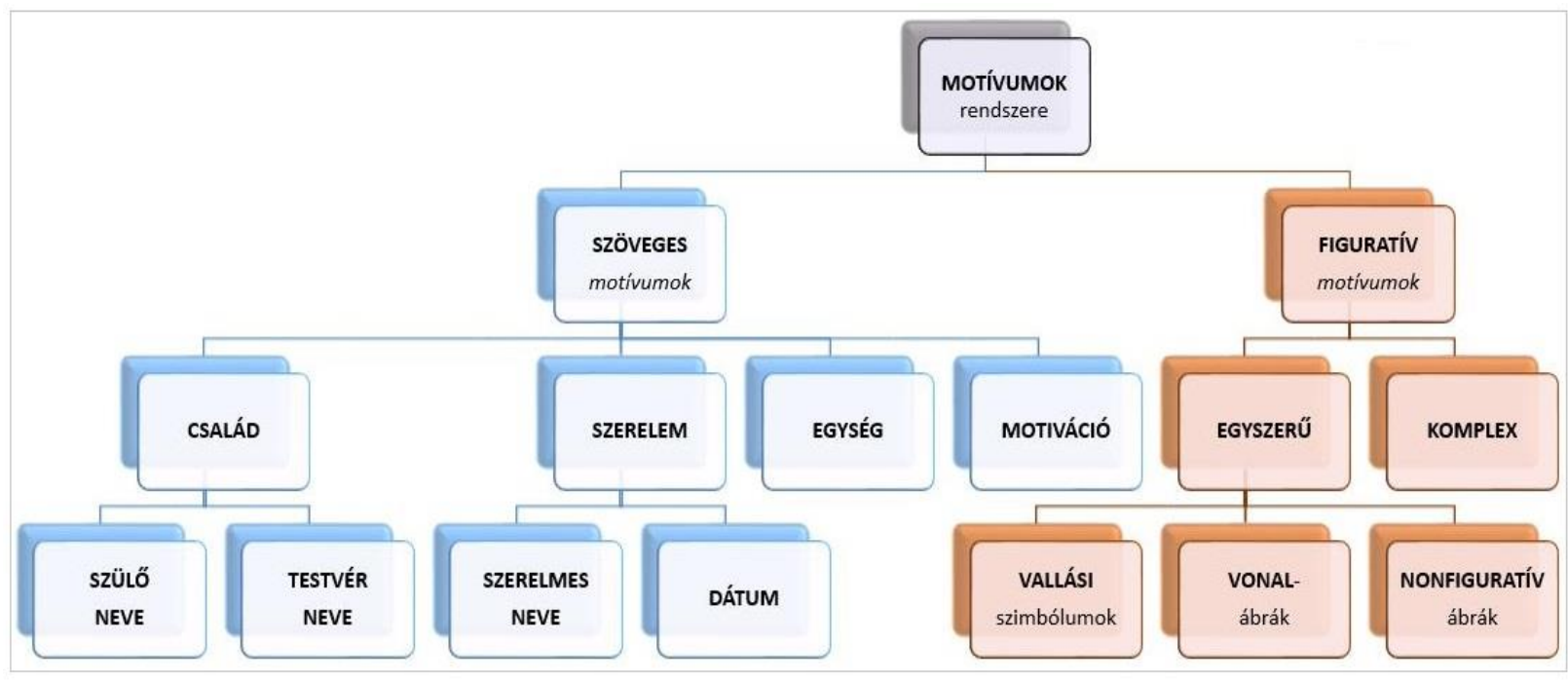

1. ábra. Motívumok rendszere

A szöveges és figuratív motívumok százalékos aránya 65-35\%. Ennek a megoszlásnak több oka is lehet. Egyrészt a házi tetoválógépek ${ }^{17}$ nem alkalmasak szépen kidolgozott, komplex minták elkészítésére, másrészt a deprivációk időszakos kielégítéséhez nincs szükség komolyabb figuratív megjelenítésre. Ha valakinek hiányzik az édesanyja, akkor egyszerüen többször felíratja magára, hogy anya, nem gondolkodik olyan jól strukturált ábrákban, melyek az anya hiányának kifejezésére szolgálnak. A továbbiakban sorra veszem az általam felállított, fentebb bemutatott kategóriarendszer egyes egységeit és a hozzájuk tartozó különböző mintákat, melyek közül többet jelentéstartalom szerinti elemzés alá vonok.

\footnotetext{
${ }^{16}$ A fejezethez tartozó képanyag a tanulmány végén található.

${ }^{17}$ A házi tetoválógépek elkészítéséről és használati módjáról bővebben Lőrincz 2017c.
} 
A szöveges motívumok talán nem igényelnek hosszas magyarázatot, hiszen a feltetováltatott szavak és nevek egyértelmüen árulkodnak jelentéstartalmukról és belső üzenetükről. A családi konnotációjú motívumok célcsoport alapján két részre oszthatók: a szülők/nagyszülők nevei, illetve a testvérek nevei. Ezek a nevek az esetek többségében a fiatal saját kézírásával kerülnek fel a bőrre.

A mintában 7 ,,anya”, 2 ,apa”, 2 „,mama” és 1 „family” tetoválás utal a felmenők iránti igényre, valamint 10 esetben szerepelt a testvér neve, nevének kezdőbetủje vagy beceneve. A nevek olykor kiegészülnek egy „love” felirattal, esetenként egy kis szívecskével, kereszttel, de komplikáltabb motívumegyüttes nem fedezhető fel.

„A bal vádlimon egy Apa és egy Sanyi felirat van. Sanyi a bátyám. Itt bent készült, egyszerre irtuk fel, vagyis hát magamnak csináltam, amikor a többiek nem figyeltek. 9 éves voltam. Azért, hogy emlékezzek rájuk. A bátyám most 22 éves, ő kint van, ritkán látom." (Angéla)

„Itt van [az ujjaimon], hogy MAMA, meghalt, de nagyon szerettem. Megadott mindent, amit kellett, és amit tudott. Szerettem. Ez kifejezi, hogy szeretem, hogy emlékezem." (Tamás)

A szerelem és az intimitás megélése és kifejezése a családi kötődés hiányához hasonlóan fejeződik ki. Az aktuális szerelem neve kerül feltetoválásra, szintén a fiatal keze írásával. Fiúk és lányok egyaránt hordozzák magukon véget ért kapcsolataik nyomait, sok esetben úgy, hogy azóta már új szerelemben élnek, és az éppen aktuális partner neve is felkerült az illető bőrére. Gyakori, hogy az otthonban kialakuló párkapcsolatokban a tetoválásokat együtt készíttetik el a fiatalok, egymás nevét íratják magukra, illetve mindketten megörökítik kapcsolatuk kezdetének időpontját.

Számos esetben ezek a nevek az alkar belső részére kerülnek, és számos esetben összefüggés mutatkozik az alkaron való elhelyezés és az érzelmi zsarolás között, hiszen a partner tudatában van annak, hogy ha a kapcsolat véget ér, akkor a neve csak vágásokkal lesz eltávolítható a kedvese böréről. A mintában 11 szerelemhez kötődő tetoválás számlálható meg: 8 név, 2 dátum, illetve egy „love” felirat.

„A bal alkaromon van római számmal egy dátum, a bal csuklómra oda lett írva Andinak a neve, csak elrontottuk." (Laci)

„A bal csuklómon Robi, a barátom neve. A bal alkaromon római számmal, hogy mikor jöttünk össze." (Timi)

„,7-8 hónapja tetováltattam elöször, amikor Robi, közösen tetováltattunk.” (Timi)

Az egység mint közösség, testvériség megjelenítése ugyanolyan fontossággal bír a fiatalok számára, mint egyediségük megmutatása. Idesorolom azokat a tetoválásokat, melyek önmagukban a testvériséget mint fogalmat fejezik ki, illetve azokat, melyek két vagy több embert kötnek össze egymással. Ebben a kategóriában gyakori a kínai írásjelek használata, 
valamint egy „Leonda” kifejezéssel is találkoztam. A la onda jelentése „hullám”. Tipikus börtöntetoválásnak tekinti a szakirodalom. Magyarországon nem rendelkezik olyan erös jelentéssel, mint Latin-Amerika területén, hiszen hazánkban nincs a börtöngangeknek komoly kultusza, mégis erős valahova tartozást fejez ki. A tapasztalatok alapján ennek a tetoválásnak olyan erös szimbolikája van, hogy determinálja viselőjét ${ }^{18}$ a bünözésre (Fliegauf 2014). Ez az egyetlen olyan tetoválás a mintában, amely börtöntetoválásként él a köztudatban. Azonban elkészítése során nem szenteltek komoly figyelmet annak, hogy a felirat hibátlan legyen, és a viselője sem jelezte, hogy egy betüt elírtak. Ez a jelenség magában hordozhatja azt a jelentéstartalmat, miszerint a viselője nem tudatosan azonosul a gangek világával, hanem csupán szabadon átvette az eredeti formához tartozó képzettársítást.

Azok a tetoválások, melyek több embert kötnek össze, mindig erős kötelékként szolgálnak a felek számára. Több olyan darab is található a motívumok körében, mely 2 vagy több fiatalon is szerepel. Elöfordul, hogy a közös tetoválásoknak csak az egyik példánya készül el, a másik fél azonban meghátrál az elkészítés előtt. „Közös tetoválást csak akkor érdemes csináltatni, ha elöször neki van, és csak aztán magadnak" (Peti) - él a mondás a gyermekotthonbeli köztudatban.

„A bal karomon van egy R. R. Tetyák felirat kínaiul. Azt jelenti, hogy 'Roli és Ricsi testvérek'. Van egy fogadott testvérem idebent, úgy éreztünk egymás iránt, mintha testvérek lennénk, mindent megosztottunk egymással. Nagyon szoros volt a kapcsolatunk, rájöttem, hogy - ahogy Buddha is mondta - nem kell tízmillió haver, csak egy barát, akiben tudod, hogy megbizhatsz. Nekem ö volt az. Nem én akartam közös tetoválást, hanem ö, de végül én is beleegyeztem. Nevet és feliratot én nem akartam, ekkor mondta, hogy legyen olyan, amit hétköznapi ember nem ismer, ezért lett kínai motívum. Közös tetoválásnak indult, de ö félt, meggondolta magát. Megharagudtam rá ekkor, aztán egyre kevesebbet találkoztunk. Végül már teljesen hidegnek érzem, ahogy rám néz." (Peti)

Feltétlen bizalomra van tehát szükség ahhoz, hogy egy életre szóló közös tetoválás elkészüljön. Ebből kifolyólag barátságok omolhatnak össze, ha a megbeszélt tervektől az egyik fél visszatántorodik.

Az egymáshoz tartozás üzenetét hordozó tetoválásokhoz hasonlóan jelentős személyiségformáló erővel bírnak a különböző, önmaguk motiválását, önazonosságuk erősítését szolgáló szlogenek, szállóigék. A mindennapi életben is számtalan esetben felbukkannak ilyen töltetü tetoválások, azonban a gyermekotthonban mégis fokozottabb erővel bírnak ezek a minták. E szövegek elsősorban angol nyelven, gyakran hibás angolsággal kerülnek fel a bőrre, ebből kifolyólag sok esetben megbánást eredményeznek.

„, Never give up”, ,, Stay strong”, „Live your dreams”, „, One life, one chance”, ,, What doesn't kill you, makes you stronger" - eredeti állapotukban ezek a leggyakoribb minták. Elöfordul még ezek mellett a ,hate - love”, a ,faith”, a „King”, illetve a „Bad boy” kifejezés is. Előbbiek motivációs tényezőként, utóbbiak az önazonosság kifejezésére, az arra való folyamatos emlékeztetés céljából jöttek létre.

\footnotetext{
${ }^{18}$ Viselője egy 16 éves fiú, akinek saját bevallása alapján kb. 20-25 rendőrségi ügye volt az elmúlt években.
} 
„A hátamon van, hogy »ami nem öl meg, az megerösit«, ha csalódás ér, akkor erre gondolok.

A lényeg, hogy soha ne adjam fel, hinnem kell az életben. Ezek tartják bennem a lelket." (Laci)

„A mellemen van, hogy »One life, one chance«, csak nem jól sikerült. De tudom, hogy ez az egyetlen életem van." (Zsolti)

„Hate és love, ez jellemzö ránk. Szeretünk és gyülölünk az életben, ez ezzel jár." (Tamás)

Egyéni esetekben elöfordul, hogy nem helyes formában jelennek meg ezek a szövegek, így született meg például a „,never goes up”, illetve a ,what does not kill you strong”. Előfordul, hogy ikertetoválásokként élnek ezek a minták, vagyis a közösség több tagján is megjelenik egy-egy sor.

A szöveges motívumok túlnyomó többsége ellenére a figuratív ábrák is teret hódítanak. Bár üzenetük nem ennyire explicit, mint a már ismertetett elemeké, de ebben rejlik a sajátos varázsuk. Ahogy a mindennapi ember kedvenc motívumaiból, illetve életét leginkább jellemző ábrákból kiépít egy komplex jelrendszert, úgy a gyermekotthon fiataljainak is vannak saját szimbólumaik. Ezeket vagy egyszerủen, önálló jelként tüntetik fel a bőrükön, vagy több szimbólum kombinálásával egy üzenetegyüttest alakítanak ki.

Az egyszerü motívumok körében külön kategóriába sorolhatók a vallási szimbólumok. Egy rózsafüzér kivételével minden - ebbe a kategóriába sorolható - tetoválás keresztet ábrázol. De mennyire utalnak ezek vallási elkötelezettségre vagy a hitbe való kapaszkodásra? Elmondható, hogy a legkisebb mértékben sem. A nevelők elmondása előrebocsátotta, a fiatalok történetei pedig csak tovább erősítették ezt a tényt.

A különböző stílusú és méretủ keresztek elkészítésének legjellemzöbb oka, hogy egyszerü elkészíteni. Nem igényel színezést, satírozást, árnyékolást, néhány egyenes vonal megrajzolásával teljesen felismerhetően elkészíthető. Azon tetoválások között, amelyek csak a kinézet kedvéért készültek, a legnagyobb arányban keresztek fordulnak elö.

„Petin van egy kereszt, de nem mondanám, hogy vallásos, mert nem az. Egy motívum, ami tetszett neki, de nincs igazán jelentösége." (Enikő, csoportvezetö nevelö)

„A bal lapockámon van egy kereszt, körülötte lefelé tekeredik egy rózsafüzér és alatta is van egy kis kereszt. 18 évesen csináltattam, egy tetkófüzetböl kinéztem, megtetszett." (Feri)

„A vállamon a kereszt egy hülyeség, nincs jelentösége.” (Máté)

„A bal kézfejemen vagy egy kereszt, igazából csak úgy szerettem volna egy szép keresztet." (Laci) 
Az egyszerüen elkészíthető keresztmotívumhoz közel álló, általam „vonalábráknak” nevezett tetoválások egy kevésbé körülhatárolt, tematikailag nem strukturált kategóriát töltenek ki. Idetartozik minden, amit maximum néhány vonal meghúzásával el lehet készíteni. Csillagok, hangjegyek, virágok, cannabis, denevér, dobókocka. E motívumok felsorolása is a változatosságról tanúskodik. Különböző minták, különböző személyiségekről árulkodnak. A virágok elsősorban lányokon feltünő darabok, melyek a nőiességet, az elrejtendő törékenységet szimbolizálják, míg a többi jellemzően a fiúk esetén megjelenő motívum. A csillagok, a hangjegyek, a denevér repülése olyan magaslatok elérését teszik lehetővé, amelyek a hétköznapok megpróbáltatásai során el sem képzelhetők. Elöfordulnak olyan szimbólumok, melyek nyíltan kábítószer-használatra vagy kábítószer-használói múltra utalnak, ilyen például a cannabis.

„A bal alkaromon van egy cannabis jel, azt azért csináltattam, mert a múltamra emlékeztet, amikor még drogoztam.” (Zsolti)

„Egy nonfi sas van a mellkasomon, házilag készitette egy idebent lakó srác és a bátyám. Elkísértem a bátyámat tetováltatni, és akkor mondtam, hogy én is szeretném ezt. Felkarcolták a mintát, majd’ bekakáltam, le lettem fogva, de annyira akartam, hogy kibirtam." (Peti)

Ezektől az ábráktól nem állnak messze a nonfiguratív motívumok, melyek legtöbbször első tetoválásként készültek, amikor még nem tudta az egyén, hogy milyen mintával fejezheti ki azt, ami benne rejtőzik, illetve csak ki akarta próbálni, hogy bírja-e a tetoválással járó fájdalmakat. Ennek tükrében a teljes mintában csupán elenyésző számban fordulnak elő nonfiguratív motívumok (mára több ilyen darabot eltakartak vagy magától kikopott).

Komplexebb minták csekély számban jelennek meg az intézmény falain belül. Két olyan, tudatosan kiépített szimbólumrendszerrel találkoztam, amely valóban a fiatal életéből merített, általa összeállított motívumkincset foglal magába. Ez a két minta egy nagy mintává egyesül az egyik fiú karján.

Bár ez a tetováláskompozíció nem a gyermekotthon falain belül készült, hanem egy „házi jellegü” tetoválószalonban, mégis maradéktalanul helyet érdemel a többi tetoválás között. Minőségileg és mennyiségileg egyaránt kiemelkedő, illetve szimbólumrendszere teljes mértékben tükrözi az elmúlt 20 év keserves tapasztalatait. A családtól elszenvedett sérelmeket, az érzést, amit az okoz, hogy az embert a saját édesanyja meglopja és kitagadja a családból. A családból való kiemelés és a gyermekotthonban való elhelyezés traumáját, azt, hogy hazaköltözése után a fiúnak magának kellett úgy döntenie, hogy újra elhagyja családját, és visszaköltözik az intézménybe.

„Két növérem, egy bátyám és egy húgom volt bent, de mindenki kiköltözött. Én visszajöttem, mert én vagyok a család feketebáránya. Anya lenyúlt 3 millió forintot és megmondta, hogy utál. Így magamtól visszajöttem, azóta újra itt vagyok 3 éve. Dolgozom mint segédmunkás, minden pénteken 36 ezer forintot kapok. Ez az elsö nyaram, amit végigdolgoztam, fogytam 21 kilót, nagyon fura. 
Magamnak megveszek mindent, amit kell, az intézetböl nem kapok semmi pénzt, csak ételt meg szállást." (Peti)

Ez a tetoválás számtalan életrajzi ihletésü szimbólumot tartalmaz, ha ezeket lehámozzuk egymásról, minimum tíz különböző motívum tárul a szemünk elé. A jelenlegi minta egy régi, elrontott tetoválás takarását is szolgálja, amely a karon felfelé kúszó hangjegyeket ábrázolt. Bár a mintát eltakarták, maga a szimbólum megmarad az új kompozícióban is. Ezek a hangjegyek a zene iránti szeretetet, annak gyógyító erejét fejezik ki. A tetoválás viselöje gyermekkorában énekelt és zongorázott, amit hosszú évek után abba kellett hagynia. Ezekkel a jelekkel állít emléket a múltja egy szép darabjának. Ennek kifejezését egy violinkulcs is erősíti a csuklón. A tetoválás alapját egy kígyópikkely-borítás képezi, mely a bünbeesés jele, az eredendő bün, ami ember voltunkhoz kötődik, illetve a család felől a gyermekek irányába elkövetett bűnök megtestesítője. A megjelenő kis házikók az intézetet szimbolizálják. Az egymás mellett álló házikók a bent töltött évek hosszú sorát, a bent ragadást, a gyermekvédelmi rendszerben élés kilátástalanságát jelképezik. Adatközlőm szerint mégis nagyon fontos, hogy ebben az állapotban is tudjuk, hogy nem szabad beleragadni az élet nehéz helyzeteibe. Ezt a nézetet testesítik meg a halak és a pókok. A halak tavirózsák közt úszkálnak, amelyek a természet tisztaságát, nyitottságát és ennek az érzésnek a szeretetét fejezik ki, emellett a folyóban úszó halak a haladást közvetítik. Akárhogy is alakul, mindig haladni kell az árral, sosem szabad megállni. Ha azonban mégis megállásra kényszerül az ember, legyen olyan, mint a pók. Mindig másszon olyan helyre, ahol nem látja senki, ahol meg tud bújni, és ahonnan mindent lát. Mások tudta nélkül mindent tudni és látni, ez hatalmat ad. A Nap és az angyalszárnyak egy olyan magaslatot nyitnak meg, mely a Földön állva nem érhető el. A Nap, amely minden fájdalom és borzalom ellenére ragyog, és az angyalok, akik minden helyzetben felsegítik az elesettet. Végül kis manósapkák, melyek némileg csökkentik a szakrális energiákat, de irányt mutatnak egy hétköznapi életünktöl eltérö világ felé.

E minta komplex jelentéstartalma (melyet adatközlőm segítségével sikerült feltárnom és elemeznem) egyben kifejezi mindazt, amit megfigyelésem és interjúim során én magam is megtapasztaltam. Úgy gondolom, hogy ha e motívumvilág jelentéstartalmát minden állami gondozott fiatal ismerné, nagy százalékával maga is azonosulni tudna. Hiszen olyan életvitelhez és személyes traumákhoz (amelyek ebben a közösségben közös traumák) kötődnek, melyekbe mindenki képes belehelyezni magát. A motívumrendszer személyességét mi sem bizonyítja jobban, hogy adatközlőm elmondása szerint még soha, senkivel nem beszélt tetoválásai jelentéséről.

A jövőre nézve többeknek van már tudatos elképzelése. „A lányom nevét szeretném majd a karomra"19 - mondja egy jelenleg terhessége 7. hónapjában járó lány. Az efféle határozottság mellett, ennek vizualizálása érdekében előfordul, hogy telefonos applikációk segítségével helyezik el a magukat ábrázoló fotókra az elképzelt mintákat, így tervezgetve a későbbiekben megszülető (vagy soha meg nem születő) ábrákat.

\footnotetext{
${ }^{19}$ Részlet az Angélával készített interjúból.
} 
4. „A tetoválás olyan, mint egy csomag cukor” - A tetováláshalmozás mint jelenség

A kutatásom során megszólaló fiatalok szinte mindannyian halmozzák tetoválásaikat, különböző minták sokaságából gyüjteménnyé formálják testüket. A posztstrukturalista megközelítés értelmezésében az ember teste nem egy eleve adott realitás. A test nem születik, hanem „gyártódik” (Fallah 2012). A fiatalok tetoválásaik segítségével hoznak létre maguk számára egy olyan testet, melynek kialakulásában múltjuk eseményeinek megjelenítése kardinális szerepet játszik. Ezekkel a képekkel saját testüket olyannyira egyedi és egyéni produktummá alakítják, mint amennyire sajátjuknak mondhatják életüket és az abban megélt eseményeket. Mint ahogy emlékeik, úgy a bőrük vászna sem vehető el tőlük.

A tetoválásgyüjtés egyszerre egyéni és társas folyamat. A gyüjtő belső indíttatásból kiválaszt egy stílust, amelyet a másokkal való interakciója során elhelyez a testén. A tetoválásgyüjtés transzformatív élménynek tekinthető, hiszen pszichológiai, szubkulturális és fizikai is egyben (Vail 1999). A kiválasztott minták belső információkat közölnek, mesélnek viselöjükröl. Egy adott kultúrához, közösséghez való tartozás fejeződik ki benne a minták vagy a tetoválás elkészítésének folyamata kapcsán. Az ember lelke, kulturális azonossága, illetve fizikai teste is igénybevétel alá kerül egy tetoválás elkészítése során.

A gyermekotthonban élö fiatalok belső indíttatása a tetováltatásra elsősorban a családi élettől való megfosztottság és az intimitás hiánya. A „stílus”, amelyet kialakítanak maguknak, leginkább egy gyermeki fájdalommal átitatott börtön-stíluskészlethez hasonlítható. A halmozás jelenléte pedig nem tekinthető meglepőnek, hiszen a bennük tomboló depriváció, fájdalom és szeretetigény (hogy szeressék őket és hogy ők is szerethessenek) nem lankad.

„Én be szeretném fejezni a tetováltatást, de ez olyan, mint mikor veszel egy csomag cukrot. Veszel egyet, »jaj, de finom«, de nem kell több, mert fogyózol. De elmész mellette és »na, még egyet« és még egyet és egyre többet kívánsz, nem bírod abbahagyni. Rájössz, hogy kell neked.” (Peti)

5. „Már nem vagyok boldog” - Megbánt tetoválások

Amilyen gyorsan elkészülnek ezek a tetoválások, szinte ugyanolyan gyorsan képesek megbánást is kiváltani viselöjükből. A megbánás okait is több kategóriába sorolhatjuk. Legmagasabb számban a „rossz emlékeket idéz elő” és a „csúnya, elrontották” indoklás jelenik meg. Emellett előfordul, hogy egyszerüen csak együtt élnek a mintával, semleges viszony füzi őket hozzá. Persze olyanokkal is találkozunk, akik elégedettek tetoválásaikkal, és egy percig sem bánták meg őket.

Mikor arról számolnak be, hogy rossz emlékeket idéz fel bennük az adott minta, két irányba ágazik el a mélyebb indoklás. Vagy egy már elveszített szerelem a megbánás oka, vagy pedig az életük egy olyan szakaszára emlékezteti őket, amikor drogoztak, hamis barátokkal álltak kapcsolatban. Olyan időszakokra, melyeket csalódásként élnek meg saját magukkal szemben. 
„Ezt a tetkót szeretném eltüntetni, mert mindig a múlt jut róla eszembe, azt hittem, ha ránézek, mindig boldog leszek. De már nem vagyok boldog. ” (Peti)

Mégsem ezek az érzelmi okok az elsődlegesek, hanem a tetoválás kivitelezése. Kétszer annyi fiatal szeretné tetoválását azért eltüntetni, mert „csúnya”, mint ahányan érzelmi okokból kívánnak nélkülük tovább élni. Sokan felismerik, hogy túl fiatalon készültek a tetoválásaik, és az idő előrehaladtával egyre csak csúnyább lesz, deformálódni fog minden minta.

„Megbántam őket. A kézfejemet és az Andi-t, mert nem maradt a börömben jól. Nem úgy sikerült, ahogy szerettem volna." (Laci)

„Az egészet eltüntetném, felnövök és még csúnyább lesz. Elnyúlik, meg minden.” (Máté)

Ehhez kapcsolódóan nagy általánosságban elmondható, hogy az első tetoválások gyakorta megbánást eredményeznek. Nem az emlékek maró hatása miatt vagy felelősségérzetből, hanem azért, mert a legtöbben ráébrednek, hogy nagyon fiatalon csúfították el a testüket egy indokolatlan tetoválással. Hiszen ezek a minták elsősorban csak azért születnek, hogy „legyenek”, érdemi belső motiváció nem vezérelte elkészültüket.

„Egy »horogkereszt« volt a bal vállamon, egy hangjeggyel takartuk el. Elmentem anyuval tetováltatni, mondtam, hogy én is ki akarom próbálni. Szerettem volna egy nonfis valamit, de az egész nonfi úgy nézett ki, mint egy félkörökböl álló horogkereszt. Nem is hordtam sokáig atlétát. Nem én választottam, csak rám ütötték. Könyörögtem érte, de nagyon megbántam.” (Peti)

„Sokan lenéztek, hogy már 14 évesen tetkóm van. De nem érdekeltek, csak egy idő után meguntam és szégyelltem saját magam, hogy már 14 évesen tetkóm van." (Máté)

Mindezek mellett egy meghökkentő esettel szembesültem, amikor a következő választ kaptam a megbánásra vonatkozó kérdésemre: „Én istenhívő vagyok és Isten a Bibliában azt mondja, hogy soha ne tetováltass magadra. ${ }^{20}$ Úgy veszem ezeket, mintha nem is lennének rajtam. Nem azt mondom, hogy bánom, csak nem fér össze a nézeteimmel. De nem takartatnám el öket." (Timi) Ezzel az esettel azt szeretném példázni, hogy egyedi helyzetek is előfordulnak, és nem süríthetők az egyének feszes kategóriákba.

Összességében elmondható, hogy a megkérdezettek körében jellemző a tetoválás megbánása. A megbánás minden válfaja a csalódottságnak tudható be, csalódás egy személyben, csalódás a minőségben, csalódás önmagukban, leginkább naivitásukban. Azzal, hogy később egy tetoválószalonban szeretnék eltakartatni vagy átalakítani tetoválásaikat, nemcsak az a céljuk, hogy dekoratívabbá váljanak, hanem a saját magukba vetett hitük megerősítése is kardinális jelentőségü.

20 „Ne vagdaljátok be testeteket halottért, és ne végezzetek magatokon tetoválást. Én vagyok az ÚR!” (3 Mózes 19:28). 
Ahogy azt Volentics Anna mondja, el kell fogadnunk, hogy a gyermekkor (fiatalkor) az ember fejlődésének minden további részétől eltérő szakasza. Ebben a fejlődési fázisban ugyanis az embernek ,alanyi joga van a tévedéshez, botladozáshoz, s nem csak a járástanulás szakaszában, s nem csak mozgásos fejlődésében” (1996: 260). Ez az állítás vonatkozik a testmódosítás lehetőségeire is. Nem rendelkeznek (ön)segítő eszközök tárházával, megküzdési stratégiákkal. Valós tapasztalat, hogy a fiatalok egy tetoválás elkészítését életük egy tévedésével, botlásával azonosítják, de ahogy a járás megtanulásához a gyermeknek néha el kell esnie, úgy ezek a fiatalok is saját börükön tapasztalták meg, hogy egy-egy tetoválásnak milyen ára van. Az ilyen helyzetbe kerülteket inkább segíteni kellene, mint büntetni. Szidás helyett segítő kezet és megoldási stratégiákat nyújtani. A züllött, hibát elkövető gyermekeket sem eltaszítani kell, hanem meg kell őket menteni a társadalom számára. Szeretettel és odafigyeléssel jobb belátás felé kell őket terelni (Hegedűs 2010).

6. „Amikor felnőtt leszek...”

„Egy vizsgán azt mondta nekem az elnök, hogy lehet, hogy jó a teljesitményem, de mit szólnék hozzá, ha azt mondanák, hogy hiába jó az ajánlólevelem és a végzettségem, de egy agyontetovált roma srácot nem szivesen fogadnának. Lehet, hogy jó a beállitódásom és a referenciám, de meglátják a tetoválásaimat és félni fognak tölem. Én azt mondtam neki, hogy tudomásom szerint az egyenruha hosszú ujjú. Nekem azért vannak igy a tetoválásaim, hogy takarhassam öket. Nem volt vele gondom, sok helyen vagánynak tartották, de érzem és tudom, hogy később, komolyabb helyre nem mehetek el rövid ujjúban." (Peti)

Ritka példája ez a jövőbe tekintő, tudatosan tervezett tetováltatásnak. Azonban annak ellenére, hogy a többség fejében nem körvonalazódik a tetoválás elkészítésekor, hogy 10-20 év múlva hogyan fogják őket viselni, határozott álláspontot képviselnek abban a kérdésben, hogy a munkaerőpiaci viszonyok és jövőbeli családi életük hogyan lesznek összeegyeztethetők díszeikkel.

Adatközlőim egyöntetüen úgy gondolják, hogy munkahelyükön nem lesz diszkriminatív hatású, hogy tetoválásokkal rendelkeznek. Azokban a szakmákban, melyekben tanulmányokat folytatnak (mint például a kertész, csontozó, pék és a hegesztő), nem vélik releváns problémának azt, hogy megjelenésükhöz tetoválások társulnak.

Leendő gyermekeiket tekintve szintén egyöntetü válasz született. Arra voltam kíváncsi, hogy születendő gyerekeiknek elmesélik-e majd fiatalkori élményeiket, melyek tetoválásaikhoz kötődnek. A válaszok során a tetoválásokon túlmutató célokat ismertem meg.

„Elmondok majd mindent nekik, felnönek majd és megértik.” (Tamás)

„El fogom mesélni az életem, hisz ott lesz rajtam.” (Zoli)

Tetoválásaik - még ha addigra esetleg takarás fedi is majd őket - fiatalságuk, múltjuk útmutatójaként lesznek jelen az életükben. Ezek által vizualizálni tudják majd gyermekeik 
számára, hogy min mentek keresztül. Ebböl a traumatizált kontextusból fakadhat, hogy többen azt mondták, hogy nem fogják gyermekeiknek megengedni, hogy tetováltassanak.

„Mikor gyerekem lesz, már hátrányos lesz a tetkó, rossz. A gyerek látja és ö is ezt fogja csinálni. Ezt nem szeretném. Meg sem fogom neki engedni nagy korában sem, hogy tetováltasson." (Erika)

„Elmesélem majd neki az életemet, de megtiltom, hogy legyen tetoválása. Ez nem jó, elcsúnyítja csak a bört." (Timi)

Ennek ellenére 100 százalékos arányban szeretnének a jövőben új tetoválásokat készíttetni. Háromféle alternatíva vetődött fel a beszélgetések során: a) eltüntetni a régi mintákat szebbekkel; $b$ ) eltüntetni a régi mintákat és új mintákat készíttetni; $c$ ) a régi mintákat meghagyni és új mintákat készíttetni. Minden esetben csak a tetoválószalonban való tetoválás az elfogadható számukra a jövőben, vagy ha nem szalonban, akkor is csak olyan tetoválóval készíttetnének mintákat, aki nem házi géppel dolgozik. A tervezett minták elsősorban nevek vagy az önkifejezés eszközéül szolgáló szövegek, motívumok.

„Szeretném a Leonda feliratot eltüntetni, mert összefolyt, már nem tetszik. A bal alkaromra szeretném, hogy 'TÖRHETETLEN', a karomra pedig, hogy 'CSIBÉSZ'. Ez vagyok én." (Alex)

„A lányom nevét szeretném majd a karomra, de csak szalonban.” (Angéla)

A legtöbb esetben elmondható, hogy még soha senkivel nem osztották meg a tetoválás elkészítésére vonatkozó motivációjukat, azokhoz való kötődésüket. Családjuk és gyermekeik lesznek az elsők, akik érdemben betekintést nyerhetnek majd férjük/feleségük, anyjuk és apjuk fiatalkori gondolatvilágába, életútjába.

„Senki nem tudja, hogy mit jelent ez a tetoválás, csak én meg most már te. Soha nem beszélgettem senkivel erröl és nem is szeretnék. Tudom, és ha ránézek, tudni fogom, mi, miért van rajtam. Ez a múltam, szeretném a tetoválásaimmal lezárni a múltamat. Mint egy képeslap, ott lesz rajtam, de nem akarom átélni újra. Soha nem fogom elfelejteni, hogy honnan jöttem, de maximum a feleségemnek és a gyerekemnek fogom elmesélni." (Peti)

\section{Összegzés}

Mit üzen nekünk, szociális szakembereknek mindez? Elsősorban azt, hogy dolgunk van ezekkel a fiatalokkal: érdemi munkát kell velük végeznünk, és támogató szereplőként kell az ő útjukat egyengetnünk (kerüljünk velük bármilyen kontextusban is kapcsolatba, akár pedagógusként, szociális munkásként, esetleg nevelöként). A gyermekvédelmi gondoskodásban élő gyermekek és fiatalok többsége olyan nehéz és megpróbáltatásokkal teli életet tudhat maga mögött, melyet kívülállóként - további sérülések okozása, régi sebek feltépése nélkül - igazán nehéz boncolgatni. Márpedig csak azzal a gyermekkel alakulhat ki 
igazi együttmüködés és támogató-támogatott viszony, akit megismertünk. S a munkánk során talán ez az egyik legnagyobb kihívás, amivel szembe kell néznünk. Elérni, hogy az emberek bizalmukba fogadjanak bennünket és megosszák velünk életük tapasztalatait - ez nem könnyü. Azonban fontos, hogy merjünk kérdezni és ne tartsunk a beszélgetések kezdeményezésétől, akkor sem, ha olyan szokatlan téma kerül fókuszba, mint a tetoválások. Ha őszinte érdeklődéssel fordulunk a fiatalok (és az idősek) irányába és valódi kíváncsisággal állunk az ő testmódosításaikhoz és azok jelentéséhez, jelentőségéhez, akkor minden bizonnyal ők is őszintén be fognak számolni nekünk a tetoválásaikhoz kapcsolódó fontosabb eseményekről. Ráláthatunk azok keletkezési körülményeire, az elkészítés idejére, megismerhetjük személyes motivációjukat, azt, hogy mások hogyan ítélik meg a mintáikat és ezzel együtt őket, valamint megtudhatjuk, hogy aktuálisan hogyan viszonyulnak saját képeikhez. Mindezek több szempontból is hozzájárulhatnak egymás megismeréséhez. Egy beszélgetés során:

- számtalan olyan életeseményt említhetünk, melyre konkrétan nem kérdezhetnénk rá annak szenzitivitása miatt (például a szülők halála, a szülőkhöz való viszony; büncselekmények, letöltött börtönbüntetés; egykori kábítószer-használat stb.);

- bepillantást nyerhetünk az egyént körülvevő közösség életébe, akár baráti kapcsolatok, családi viszonyok is feltérképezhetővé válnak (például a közös tetoválások vagy az eltüntetett, elfedett tetoválások is árulkodóak lehetnek);

- az elkészítési körülményekről való diskurzus („,házi tetoválás” vagy tetoválószalonban készült minta) elindíthat egy, a személyes higiéniáról, az egészségvédelemről s ezek fontosságáról szóló további beszélgetést (a fertőzésveszély és a gyulladások kapcsán);

- a tetoválások egy életre szólnak, vagyis annak a döntésnek a meghozatala, hogy „egy mintát égetek a bőrömbe", akár a halálig meghatározhatja a külső megjelenést, ezzel az önértékelést és a társadalmi megítélést - ezzel a felelős döntéshozatalt helyezi fókuszba, és egy nagyon fontos és mindig aktuális témakörre tereli a beszélgetést;

- komoly és dinamikus ön- és társismereti folyamatok mennek végbe, s ennek köszönhetően a későbbiek során könnyebben elegyedhetünk beszélgetésbe, kevesebb gátlással fordulnak hozzánk kérdéssel, kéréssel a fiatalok, és ténylegesen kialakulhat egy őszinte érdeklődésen alapuló bizalmi viszony, ami nélkül eredményes szociális segítés és támogatás nem mehet végbe.

Elszomorító tapasztalat, hogy a többségi társadalom rendszere leírja ezeket a fiatalokat, ha tehetné, kivetné magából őket. Nincs helyük, bünözők, a jövő hajléktalanjai, reménytelenek, a társadalom koloncai - résztvevő megfigyelésem során közvetlenül is érzékelhettem ezt a fajta megítélést. Ezzel szemben úgy gondolom, hogy meg kell adnunk az esélyt mindenki számára, a fájdalommal és frusztrációval teli fiatalokra pedig kiemelkedően komoly figyelmet kellene szentelnie a társadalomnak, a rendszernek. Meg kell előzni a kriminalizálódást, a különböző addikciók kialakulását, illetve a suicid hajlam kifejlődését. A tetoválások megjelenése nem az út első lépése ezek felé a deviáns magatartásformák felé. A tetoválás segélykiáltás, hiánypótlás, önigazolás, lelkisegély-nyújtás. Mit tehetnének ezek a fiatalok, amíg a környezetük nem tesz értük semmit? Egy térképet adnak ahhoz, amin keresztülmentek, 
képekben festik le az életüket. Megmutatják a világnak azt, amik. Ne vessük meg őket ezért, inkább fejtsük meg őket.

\section{Irodalomjegyzék}

BAGDY E. (1995): Családi szocializáció és személyiségzavarok. Nemzeti Tankönyvkiadó, Budapest.

BERNE, E. (1997): Sorskönyv. Háttér Kiadó, Budapest.

BODROGI T. (1987): A tetoválás etnológiája (A személyi müvészet és müfajai). Forrás, 19/3. 110-140.

BOYTHA ZS. (2015): Állami gondozottak traumatizációja. In KURITÁRNÉ SZABÓ I. (szerk.): Úgy szerettem volna, ha nem bántottak volna: A családon belüli gyermekkori traumatizáció: elmélet és terápia. Oriold és Társa Kiadó, Budapest. 217-234.

BUDA B. (2009): Gyakran éreztem, hogy a tetoválást érdemes lenne kutatni! In SINGER M. (szerk.): Lelke rajta - A tetoválás pszichológiája. Jaffa Kiadó és Kereskedelmi Kft., Budapest. 59-72.

COHEN, A. K. (1969): A szubkultúrák általános elmélete. In HUSZÁR T., SÜKÖSD M. (szerk.): Ifjúságszociológia. Közgazdasági és Jogi Könyvkiadó, Budapest. 264-286.

CORBIN, J., STRAUSS, A. (2008): A kvalitatív kutatás alapjai. L'Harmattan, Budapest.

FALLAH N. (2012): A tetováláshalmozás motivációs háttere és személyiségdimenzió. In KÖRÖSSY J., KÖVÁRY Z. (szerk.): Fiatalok biztonságkeresési stratégiái az információs társadalomban. Primaware, Szeged. 35-61.

FLIEGAUF G. (2014): A tetoválás mint szubkulturális jelenség: marginalizálódásra utaló jelek magyar fogvatartottak tetoválásain. Börtönügyi Szemle, 33/1. 48-64.

FORBES, G. B. (2001): Collage Students with Tattoos and Piercings: Motives, Family Experiences, Personality Factors, and Perception by Others. Psyichological Reports, 89/3. 74-789.

GOLNHOFER E. (2001): Az esettanulmány. Müszaki Könyvkiadó, Budapest.

HEGEDÜS J. (2010): Gyermeksorsok, életutak a javitóintézet világából. Gondolat Kiadó, Budapest.

HEGEDÜS J., PINTYI Z. (2008): Segédanyag a gyermekbántalmazás témájához pedagógusok számára. RÉV8 Józsefvárosi Gyermekrehabilitációs és Városfejlesztési Zrt., Budapest.

HERCZOG M. (2007): Gyermekbántalmazás. Complex, Budapest.

KALDENEKKER M., PIKÓ B. (2005): A „piercing” és a „,tattoo” világa - Deviancia vagy divat? Társadalomkutatás, 23/1. 149-170.

KURITÁRNÉ SZABÓ I. (2015): A gyermekkori családon belüli traumatizáció és következményei. In KURITÁRNÉ SZABÓ I. (szerk.): Úgy szerettem volna, ha nem bántottak volna: A családon belüli gyermekkori traumatizáció: elmélet és terápia. Oriold és Társa Kiadó, Budapest. 13-52.

LETENYEI L. (2005): Településkutatás. L'Harmattan Kiadó, Budapest.

LŐRINCZ A. (2017a): Testem a vásznam. Az állami gondozott fiatalok tetováláskultúrájának kvalitatív vizsgálata. In NAGY Á. (szerk.): Tizenkilencre lapot? Szociálpedagógia a XXI. 
században. Pallasz Athéné Egyetem - Iuvenis Ifjúságszakmai Mühely, ISZT Alapítvány, Budapest. 319-343.

LÖRINCZ A. (2017b): Az otthonból az otthonról. Az „állami gondozottság” által keltett társadalmi szorongás jelenségéről. In NAGY Á. (szerk.): Iuvenis Ifjúságszakmai konferencia. Konferenciakötet. Neumann János Egyetem - Iuvenis Ifjúságszakmai Mühely, ISZT Alapítvány, Kecskemét. 73-88.

LŐRINCZ A. (2017c): „Tetoválószalon a szobám” - Hogyan készül a tetoválás egy gyermekotthon falain belül? In PROF. DR. KÉKESI T., VADÁSZNÉ PROF. DR. BOGNÁR G., DR. DABASI-HALÁSZ Zs. (szerk.): Diáktudomány. A Miskolci Egyetem Tudományos Diákköri munkáiból. Miskolc. 142-147.

MÉSZÁROS GY. (2014): Szubkultúrák és iskolai nevelés - Narratív kritikai, pedagógiai etnográfia. In GÉCZI J. (szerk.): Iskolakultúra-könyvek 48., Iskolakultúra, Veszprém.

SOLYMOSI K. (1987): A tetoválás motivációi. Forrás, 19/3. 59-65.

SPITZER GY. (2009): Öltöny alatti lázadás. In SINGER M. (szerk.): Lelke rajta - A tetoválás pszichológiája. Jaffa Kiadó és Kereskedelmi Kft., Budapest. 129-156.

SZENDI G. (2009: A tetoválásról: a test mint kulturális tárgy. In SINGER M. (szerk.): Lelke rajta - A tetoválás pszichológiája. Jaffa Kiadó és Kereskedelmi Kft., Budapest. 1132.

SYKES, G. M. (1985): Society of captives. Princton University Press, Princeton.

VAIL, A. D. (1999): Tattoos are like potato chips... you can't have just one: the process of becoming and being a collector. Deviant Behavior, 20/3. 253-273.

VOLENTICS A. (1996): Gyermekvédelem és reszocializáció. Nemzeti Tankönyvkiadó, Budapest.

\section{Felhasznált egyéb források}

1997. évi XXXI. törvény a gyermekek védelméről és a gyámügyi igazgatásról

2014. évi CI. törvény a gyermekek védelméről és a gyámügyi igazgatásról szóló 1997. évi XXXI. törvény módosításáról

Képek, ábrák: A tanulmányban szereplő képeket és ábrákat a szerző készítette.
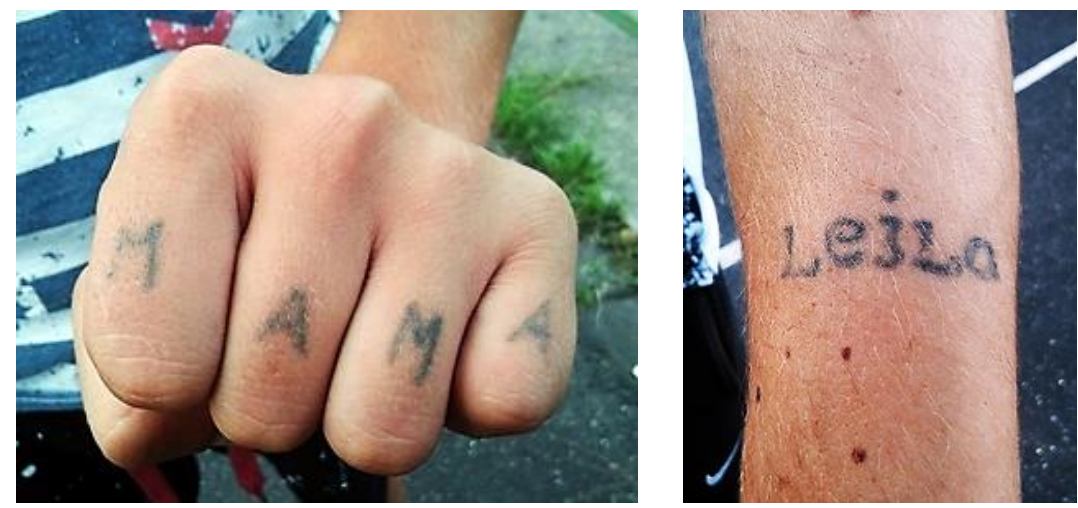

Családhoz kötődö tetoválások 

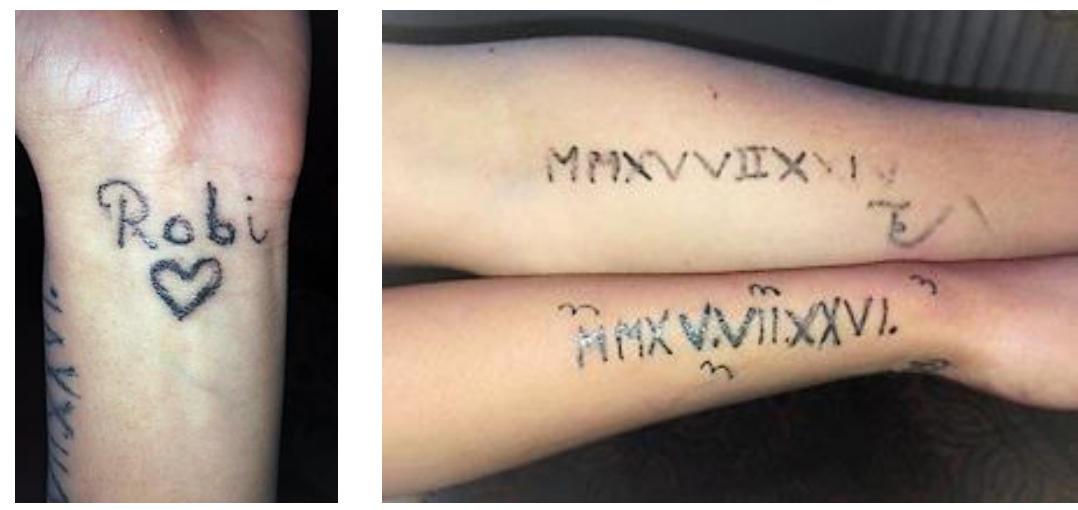

Szerelmi élethez kötődő tetoválások
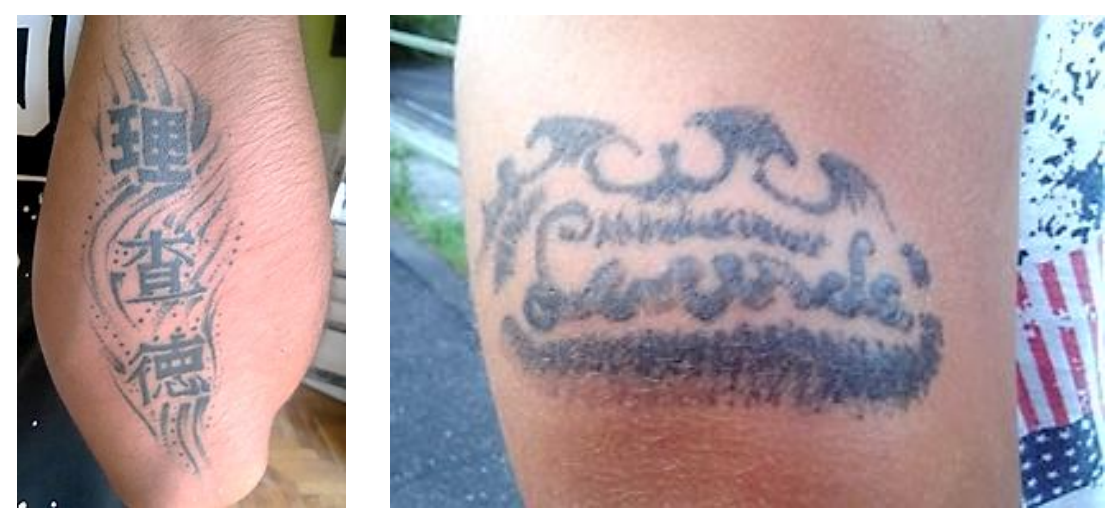

Egységet kifejezö tetoválások
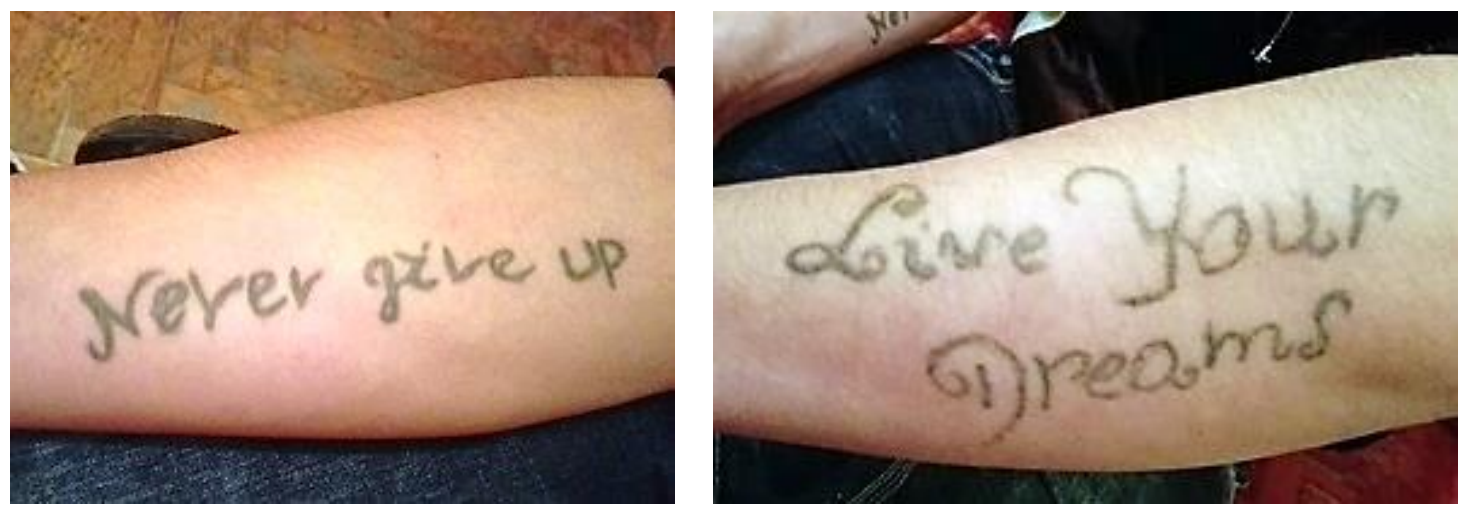

Motivációs, önazonosságot tükröző tetoválások
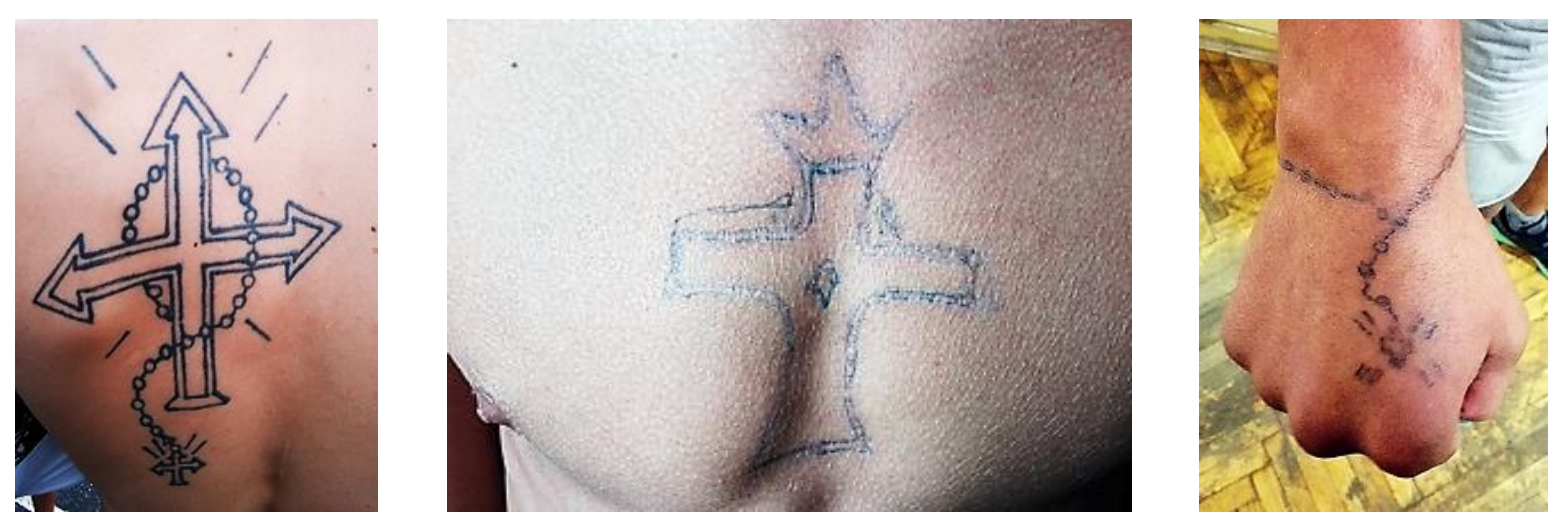

Vallási sugallatú tetoválások 

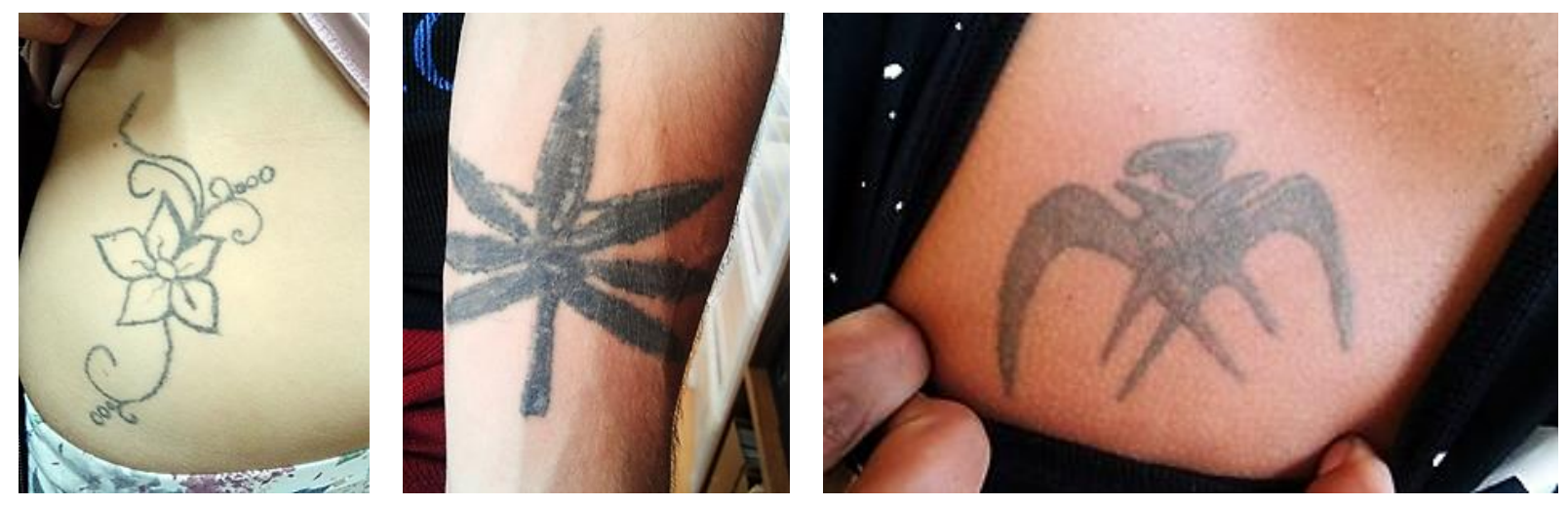

Vonalábrák, nonfiguratív ábra
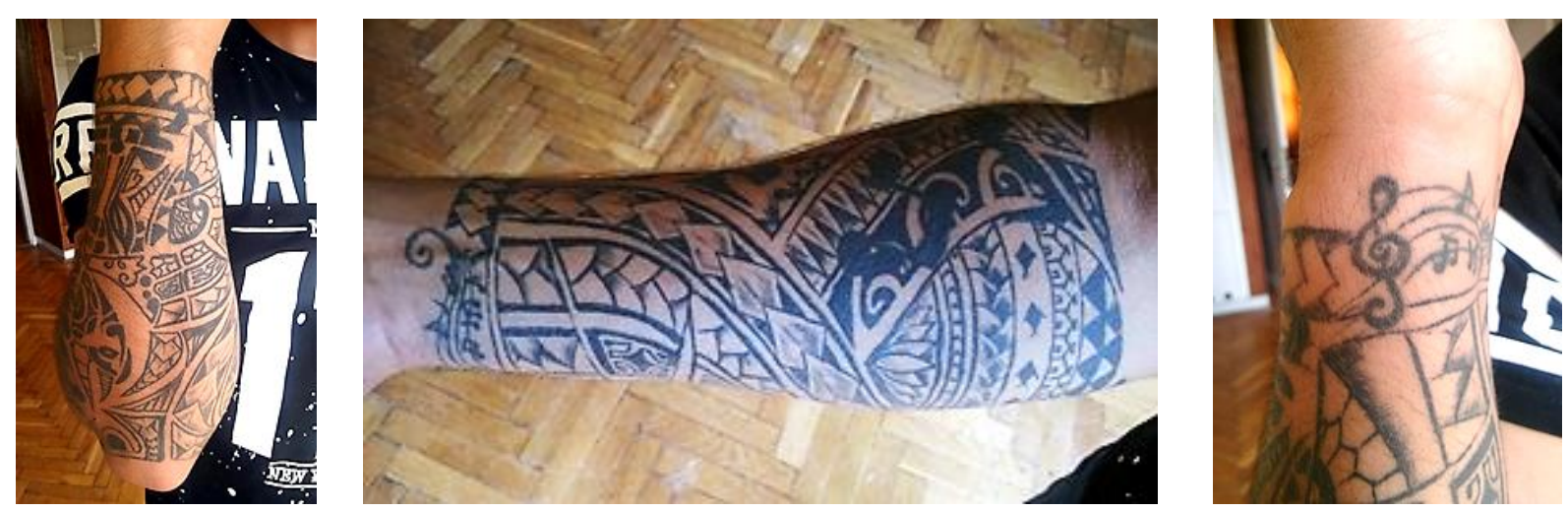

Komplex, a viselője által összeállitott szimbólumkészlet 